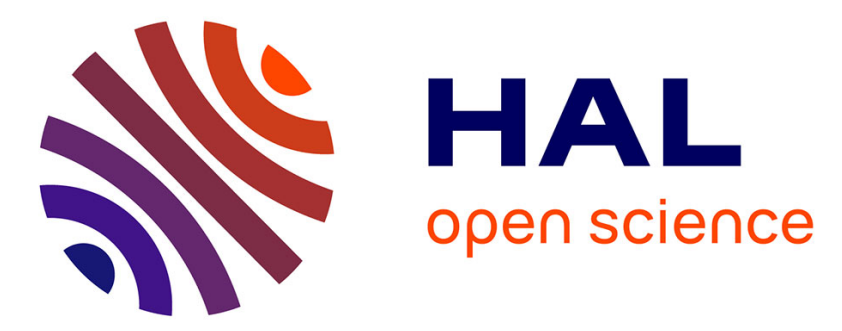

\title{
Interactions between plutonism and detachments during Metamorphic Core Complex formation, Serifos Island (Cyclades, Greece)
}

\author{
Aurélien Rabillard, Laurent Arbaret, Laurent Jolivet, Nicole Le Breton, \\ Charles Gumiaux, Romain Augier, Bernhard Grasemann
}

\section{To cite this version:}

Aurélien Rabillard, Laurent Arbaret, Laurent Jolivet, Nicole Le Breton, Charles Gumiaux, et al.. Interactions between plutonism and detachments during Metamorphic Core Complex formation, Serifos Island (Cyclades, Greece). Tectonics, 2015, 34 (6), pp.1080-1106. 10.1002/2014TC003650 . insu01145540

\author{
HAL Id: insu-01145540 \\ https://hal-insu.archives-ouvertes.fr/insu-01145540
}

Submitted on 16 Jun 2015

HAL is a multi-disciplinary open access archive for the deposit and dissemination of scientific research documents, whether they are published or not. The documents may come from teaching and research institutions in France or abroad, or from public or private research centers.
L'archive ouverte pluridisciplinaire HAL, est destinée au dépôt et à la diffusion de documents scientifiques de niveau recherche, publiés ou non, émanant des établissements d'enseignement et de recherche français ou étrangers, des laboratoires publics ou privés. 


\section{Tectonics}

\section{RESEARCH ARTICLE}

10.1002/2014TC003650

Key Points:

- Interactions between plutonism and strain localization

- Continuum of deformation from magmatic to brittle conditions

- Structural, microstructural, and anisotropy of magnetic susceptibility data

\section{Correspondence to:}

\section{A. Rabillard,}

aurelien.rabillard@univ-orleans.fr

\section{Citation:}

Rabillard, A., L. Arbaret, L. Jolivet, N. Le Breton, C. Gumiaux, R. Augier, and B. Grasemann (2015), Interactions between plutonism and detachments during metamorphic core complex formation, Serifos Island (Cyclades, Greece), Tectonics, 34, doi:10.1002/2014TC003650.

Received 24 JUN 2014 Accepted 14 APR 2015 Accepted article online 21 APR 2015

๑2015. American Geophysical Union. All Rights Reserved.

\section{Interactions between plutonism and detachments during metamorphic core complex formation, Serifos Island (Cyclades, Greece)}

\author{
Aurélien Rabillard ${ }^{1,2,3}$, Laurent Arbaret ${ }^{1,2,3}$, Laurent Jolivet ${ }^{1,2,3}$, Nicole Le Breton ${ }^{1,2,3}$, \\ Charles Gumiaux ${ }^{1,2,3}$, Romain Augier ${ }^{1,2,3}$, and Bernhard Grasemann ${ }^{4}$ \\ ${ }^{1}$ Université d'Orléans, ISTO, UMR 7327, Orléans, France, ${ }^{2} \mathrm{CNRS} / \mathrm{INSU}$, ISTO, UMR 7327, Orléans, France, ${ }^{3}$ BRGM, ISTO, UMR \\ 7327, Orléans, France, ${ }^{4}$ Department of Geodynamics and Sedimentology, University of Vienna, Vienna, Austria
}

Abstract In order to better understand the interactions between plutonic activity and strain localization during metamorphic core complex formation, the Miocene granodioritic pluton of Serifos (Cyclades, Greece) is studied. This pluton (11.6-9.5 Ma) intruded the Cycladic Blueschists during thinning of the Aegean domain along a system of low-angle normal faults belonging to the south dipping West Cycladic Detachment System (WCDS). Based on structural fieldwork, together with microstructural observations and anisotropy of magnetic susceptibility, we recognize a continuum of deformation from magmatic to brittle conditions within the magmatic body. This succession of deformation events is kinematically compatible with the development of the WCDS. The architecture of the pluton shows a marked asymmetry resulting from its interaction with the detachments. We propose a tectonic scenario for the emplacement of Serifos pluton and its subsequent cooling during the Aegean extension: (1) A first stage corresponds to the metamorphic core complex initiation and associated southwestward shearing along the Meghàlo Livadhi detachment. (2) In the second stage, the Serifos pluton has intruded the dome at shallow crustal level, piercing through the ductile/brittle Meghàlo Livadhi detachment. Southwest directed extensional deformation was contemporaneously transferred upward in the crust along the more localized Kàvos Kiklopas detachment. (3) The third stage was marked by synmagmatic extensional deformation and strain localization at the contact between the pluton and the host rocks resulting in nucleation of narrow shear zones, which (4) continued to develop after the pluton solidification.

\section{Introduction}

Over the past 30 years, intense research has been devoted to interrelations of plutonic activity and shear zone formation in various tectonic settings, from extensional [Baldwin et al., 1993; Neves et al., 1996; Turrillot et al., 2011], transtensional [Hutton, 1982], to transpressional [McCaffrey, 1992]. Within deforming continental regions, especially regions where metamorphic core complexes (MCCs) developed, plutonism interacts with processes of strain localization in the crust, and shear zone nucleation and its subsequent development are often coeval with magma crystallization. Precise fieldworks and thermochronological studies have confirmed the spatiotemporal relationship between MCC formation and plutonic activity as documented in the Basin and Range Province [e.g., Crittenden et al., 1980; Wernicke et al., 1987; Foster et al., 2001; Davis et al., 1993], the Mediterranean Region [e.g., Daniel and Jolivet, 1995; Jolivet et al., 1998; Acocella and Rossetti, 2002; Smith et al., 2011], and more recently in East Asia [Charles et al., 2011]. Correlations, in a broad sense, have been particularly documented in the Cycladic islands in the Aegean Sea [Faure et al., 1991; Lee and Lister, 1992; Koukouvelas and Kokkalas, 2003; Kumerics et al., 2005; Brichau et al., 2007; Tschegg and Grasemann, 2009; Denèle et al., 2011; Kokkalas and Aydin, 2013; Laurent et al., 2015].

Different causes were inferred to explain these spatial and temporal interactions. It was often suggested that shear zones can create space for magma ascent, while the site of pluton emplacement is controlled by preexisting or active shear zones [e.g., D'Lemos et al., 1992; Tikoff and Teyssier, 1992; Brown, 1994; Vigneresse, 1995]. An alternative view is that partially crystallized magmatic bodies represent rheologically weak heterogeneities in the crust that may trigger strain localization and shear zone nucleation [e.g., Lister and Baldwin, 1993; Davidson et al., 1994; Tommasi et al., 1994]. At the scale of a single magmatic body, how pluton interacts with extensional shear zones is still an open question. 

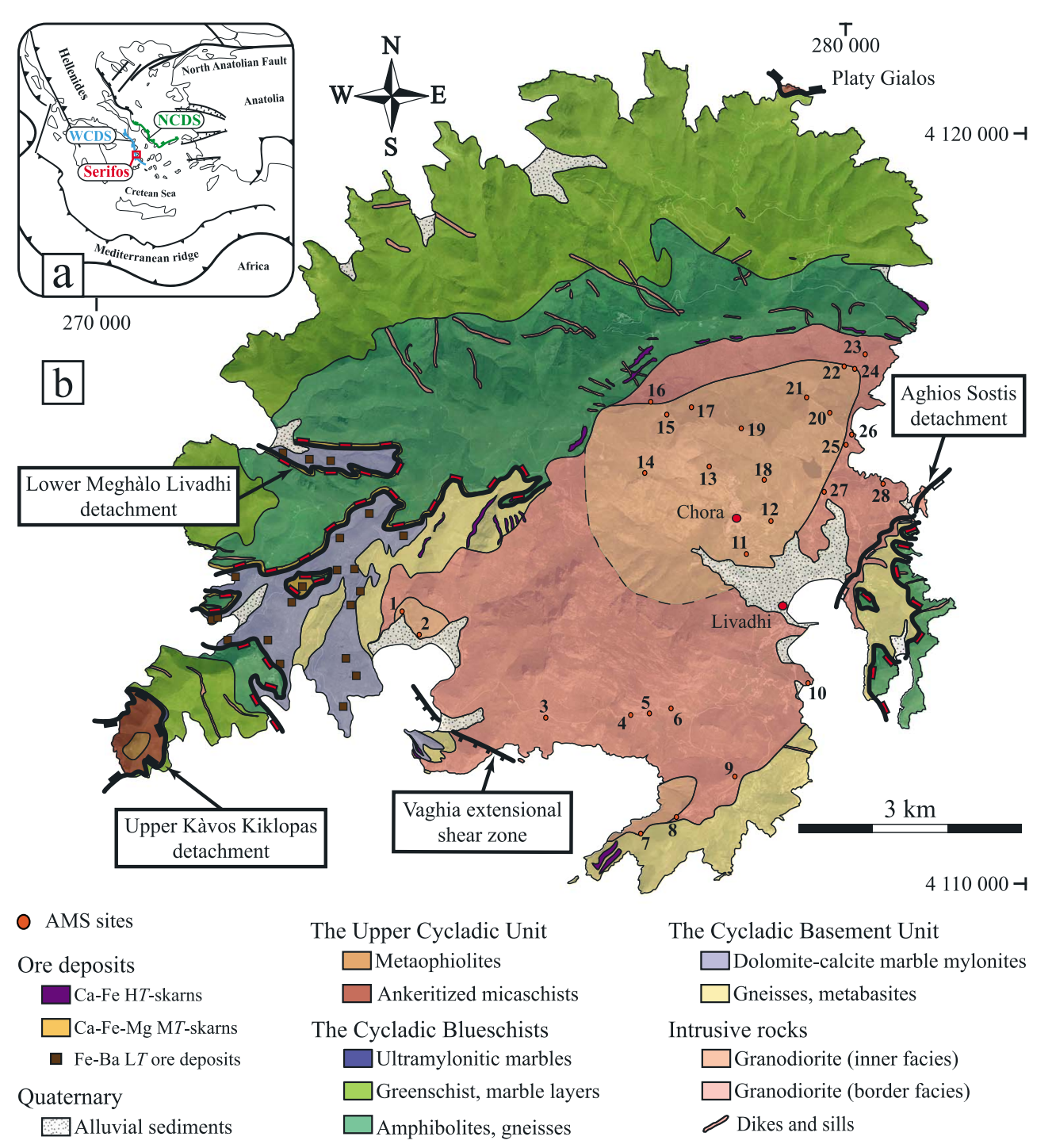

The Cycladic Basement Unit

$\square$ Dolomite-calcite marble mylonites

$\square$ Gneisses, metabasites

Intrusive rocks

$\square$ Granodiorite (inner facies)

$\square$ Granodiorite (border facies)

Dikes and sills

Figure 1. (a) Tectonic map of the Aegean region showing the main structures, the North Cycladic Detachment System (NCDS), the West Cycladic Detachment System (WCDS), and the location of Serifos Island. (b) Geological map of the studied area (modified after Salemink [1985], Grasemann and Petrakakis [2007], and Petrakakis et al. [2007]) and location of the AMS sites. Coordinates on map are given in UTM zone 35N, WGS 1984.

To better understand the feedback relationships between processes of shear localization and pluton emplacement that operate during MCC formation, it is necessary to document areas where development of crustal-scale shear zones, metamorphism, and plutonism are shown to be synchronous. The Miocene granodioritic pluton of Serifos [Altherr et al., 1982; Iglseder et al., 2009; Brichau et al., 2010], in the Cyclades (Greece), offers an example of an intrusion contemporaneous with the activity of a detachment system, namely, the West Cycladic Detachment System (WCDS) [Iglseder et al., 2011; Grasemann et al., 2012]. On the basis of a structural fieldwork, together with microstructural and anisotropy of magnetic susceptibility (AMS) data, we describe a strongly asymmetric structure at the pluton scale and a progressive evolution from magmatic to brittle deformation within the magmatic body, kinematically consistent with the dome development and associated detachments. We evaluate (1) the geometrical relationships between the Serifos pluton, host rocks, and large-scale detachments and build an original cross section; (2) the distribution of kinematic indicators inside and outside the pluton; and (3) the distribution and evolution of deformation within the pluton during its cooling. This approach leads us to propose a new model of pluton emplacement during crustal extension in interaction with extensional shear zones. 


\section{Geological and Geodynamic Setting}

\subsection{Geology and Geodynamic Evolution of the Aegean Region}

The convergence between Africa and the Aegean region is accommodated in the Hellenic subduction zone where the Mediterranean Ridge accretionary complex has developed. Back-arc active extension is restricted to the periphery of the Aegean domain with two regions of fast N-S extension, the Corinth rift and the western part of Turkey [Eyidoğan and Jackson, 1985; Armijo et al., 1996; Hatzfeld et al., 2000; Bozkurt and Sözbilir, 2004; Rohais et al., 2007; Aktug et al., 2009; Le Pichon and Kreemer, 2010]. Slower E-W extension is recorded in the Hellenic arc, southern Peloponnese, and Crete [Armijo et al., 1992; Jackson, 1994; Goldsworthy et al., 2002]. In addition to this extension, GPS measurements also record a rigid body motion of the Anatolian Plate, guided by the North Anatolian Fault, which has propagated since $5 \mathrm{Ma}$ from the Marmara Sea to the Aegean Sea [Armijo et al., 1999; McClusky et al., 2000; Reilinger et al., 2010; Pérouse et al., 2012 ].

The current deformation pattern reworks a protracted tectonic history of crustal thickening followed by extensional collapse in the back-arc region of the north dipping Hellenic subduction (see syntheses by Jolivet and Brun [2010] and Jolivet et al. [2013], and references therein). The Cycladic archipelago (i.e., the Cyclades, thereafter), in the central part of the Aegean Sea (Figure 1a), forms one of the most deeply exhumed parts of the Hellenic belt. Classically, three main units are distinguished in the Cyclades [Bonneau, 1984; Jolivet et al., 2004; van Hinsbergen et al., 2005]. From structurally lowest to highest, these units are the following: (1) The Cycladic Basement Unit (CBU) crops out on several Cycladic islands (Naxos, Paros, los, Sikinos, and Serifos) [Andriessen et al., 1987; Grasemann and Petrakakis, 2007; Huet et al., 2009]. It consists of medium to high-grade rocks (paragneiss and orthogneiss) equilibrated in the amphibolite facies conditions of Variscan or even pre-Variscan age [Henjes-Kunst and Kreuzer, 1982; Andriessen et al., 1987; Keay and Lister, 2002]. (2) The Cycladic Blueschists, a metasedimentary unit predominantly made up of metapelites and marbles with locally intercalated metabasic rocks. While these rocks preserve a conspicuous high-pressure (HP) imprint (i.e., eclogites and blueschists), the overlying (3) Upper Cycladic Unit comprises a continental basement (amphibolites, gneisses) that preserves Late Cretaceous HT metamorphic age, topped by ophiolitic material (i.e., serpentinites, gabbros, and basalts) that obducted in the Late Jurassic [Maluski et al., 1987; Katzir et al., 1996].

Two major tectonometamorphic episodes have been recognized in the Cyclades corresponding to two clusters of metamorphic ages [Altherr et al., 1979, 1982; Wijbrans and McDougall, 1988; Bröcker et al., 1993; Ring et al., 2010]. A first Eocene episode of crustal thickening was followed by an Oligo-Miocene postorogenic extension driven by the southward retreat of the African slab from approximately $35 \mathrm{Ma}$ to the present according to Jolivet and Faccenna [2000] and Jolivet and Brun [2010] or slightly younger (23-19 Ma) following Ring et al. [2010]. An earlier extension is also recognized farther north in the Rhodope Massif since $45 \mathrm{Ma}$ [Brun and Sokoutis, 2010].

The first episode is associated with high-pressure-low-temperature ( $\mathrm{HP}$ - LTT) metamorphism under eclogite and blueschist facies conditions [e.g., Trotet et al., 2001a, 2001b; Groppo et al., 2009; Augier et al., 2014]. It is largely documented in the Cycladic Blueschists but poorly recorded in the CBU. Radiometric ages range from 70 to $35 \mathrm{Ma}$ [Altherr et al., 1979; Maluski et al., 1987; Wijbrans et al., 1990; Bröcker and Enders, 1999], but most of them cluster between 50 and $40 \mathrm{Ma}$, in the middle Eocene. This HP-LT episode has been linked to the burial and the exhumation in the Hellenic subduction zone of the Cycladic Blueschists and the CBU.

The second extensional episode is related to low-pressure-high-temperature ( $\mathrm{L} P$-HT $)$ gradient that affected the two lower Cycladic units. During thinning of the Aegean domain, the Eocene nappe stack was disrupted and MCCs were exhumed below crustal-scale detachments [Lister et al., 1984; Gautier and Brun, 1994a, 1994b; Jolivet et al., 1994; Gautier et al., 1999]. Extension along the north dipping North Cycladic Detachment System (NCDS) [Jolivet et al., 2010; Lecomte et al., 2010] and the south dipping West Cycladic Detachment System (WCDS) [Iglseder et al., 2011; Grasemann et al., 2012] has led to the exhumation of the northern and western parts of the Cyclades, respectively (Figure 1a). While extension and exhumation were accommodated by detachment systems, l-type granitoids intruded the Aegean crust over few million years (17-9 Ma) [e.g., Altherr et al., 1982; Keay et al., 2001; Bolhar et al., 2010]. The Cycladic granitoids crop out on Tinos, Mykonos-Delos, Naxos, Ikaria, as well as on Serifos Island [e.g., Altherr et al., 1982, 1988; Lee and Lister, 1992]. They were temporally and spatially emplaced in close interaction with Miocene metamorphic domes and associated crustal-scale detachments [Faure et al., 1991; Lister and Baldwin, 1993; 
Koukouvelas and Kokkalas, 2003; Brichau et al., 2007, 2008, 2010; Grasemann and Petrakakis, 2007; Denèle et al., 2011; Laurent et al., 2015].

\subsection{Geology of Serifos Island}

Architecture of Serifos Island is described as a MCC [Grasemann and Petrakakis, 2007; Grasemann et al., 2012] intruded by an l-type granodiorite that was emplaced above the brittle-ductile transition zone [Marinos, 1951; Altherr and Siebel, 2002; Iglseder et al., 2009; Stouraiti et al., 2010]. Two main petrographic facies have been recognized within the kilometer-scale Serifos granodiorite (Figure 1b). The inner facies is described as a fine-grained and equigranular, nonfoliated granodiorite, while the border facies is foliated, coarse-grained, and locally contains enclaves [Salemink, 1985]. Geobarometry using the total aluminum content of amphiboles from the Serifos pluton suggests emplacement and cooling at shallow crustal levels, around 8-12 km [Stouraiti and Mitropoulos, 1999; St. Seymour et al., 2009]. Emplacement age of the main pluton and the associated dikes span over $2 \mathrm{Ma}$ between 11.6 $\pm 0.1 \mathrm{Ma}$ and $9.5 \pm 0.1 \mathrm{Ma}(\mathrm{U} / \mathrm{Pb}$ zircon ages [Iglseder et al., 2009]). Cooling ages (K-Ar hornblende age of $9.5 \pm 0.3 \mathrm{Ma}$ and $\mathrm{K}-\mathrm{Ar}$ and $\mathrm{Rb}-\mathrm{Sr}$ biotite ages of $8.6 \pm 0.2 \mathrm{Ma}$ ) indicate a rather fast cooling after emplacement [Altherr et al., 1982]. Additionally, Iglseder et al. [2009] reported $\mathrm{Rb}-\mathrm{Sr}$ biotite ages between $8.5 \mathrm{Ma}$ and 7.7 Ma. Furthermore, both zircon and apatite (U-Th)/He ages from the Serifos granodiorite and its host rocks plot between $8 \mathrm{Ma}$ and $5 \mathrm{Ma}$ [Altherr et al., 1982; Hejl et al., 2002; Grasemann et al., 2012], indicating a common cooling history within the brittle crust. Brichau et al. [2010] reported slightly older apatite and zircon fission track ages ranging from $13 \mathrm{Ma}$ to $6 \mathrm{Ma}$.

The late Miocene Serifos pluton has intruded into a sequence of metamorphic rocks that can be subdivided in three distinct units (Figure 1b). From bottom to top of the tectonic stack, Grasemann and Petrakakis [2007] described (1) gneisses and dolomite-calcite marble mylonites of the CBU; metabasite intercalations within gneisses are also identified by Salemink [1985]; (2) amphibolites intercalated with gneisses, as well as greenschists intercalated with marbles belonging to the Cycladic Blueschists; and (3) marbles dominated cataclastic lithologies, metabasites, and serpentinites of the Upper Cycladic Unit. These units are separated by two branches of low-angle normal faults belonging to the WCDS [Grasemann et al., 2012]. They show similar NE-SW oriented stretching lineation with top-to-the-SW shear sense [Grasemann and Petrakakis, 2007; Petrakakis et al., 2007; Grasemann et al., 2012]. The lower detachment, called Meghàlo Livadhi detachment hereafter, separates the CBU from the Cycladic Blueschists, while the upper one, named Kàvos Kiklopas detachment hereafter, separates the Cycladic Blueschists from the Upper Cycladic Unit. On the basis of thermochronological data, cooling ages obtained on both the Cycladic Blueschists and the CBU range from 15 to $6 \mathrm{Ma}$ (Rb/Sr muscovite ages [Iglseder et al., 2009], ${ }^{40} \mathrm{Ar} /{ }^{39} \mathrm{Ar}$ ages on muscovite [Grasemann et al., 2012], and zircon and apatite (U-Th)/He ages [Brichau et al., 2010]). Besides, approximately 15-11 Ma ages are ascribed to mylonitization over the Meghàlo Livadhi detachment. Along its western margin, the magmatic body pierces the Meghàlo Livadhi detachment. Furthermore, the eastern margin of the granodiorite is deformed by an additional detachment (Aghios Sostis detachment hereafter) that shows an evolution from ductile to brittle conditions during cooling and exhumation [Tschegg and Grasemann, 2009].

While the stretching lineation trends NE-SW with a clear top-to-the-southwest sense of shear along the two detachments, a well-preserved E-W to ENE-WSW oriented stretching lineation with top-to-the west shear sense can be found throughout the $\mathrm{CBU}$ and the Cycladic Blueschists. Previous ${ }^{40} \mathrm{Ar} /{ }^{39} \mathrm{Ar}$ analyses on white micas of the Cycladic Blueschists preserve ages of 38-35 Ma [Schneider et al., 2011], suggesting that the E-W to ENE-WSW trending lineations were the result of an earlier phase of deformation within the western Cyclades, predating the NE-SW directed extension [Grasemann et al., 2012].

\section{Large-Scale Structures in Metamorphic Host Rocks}

3.1. Meghàlo Livadhi Detachment

3.1.1. Southwestern Part of Serifos Island

Meghàlo Livadhi Bay marks the location of the lowermost low-angle normal fault that separates the CBU and the Cycladic Blueschists (Figures 2a, 3a, and 3b). The west dipping detachment evolved from ductile to brittle conditions. At deeper structural levels, dolomite-calcite mylonitic marbles and gneisses belonging to the CBU display an E-W to ENE-WSW trending stretching lineation with consistent top-to-the-W kinematic indicators such as sigma and delta feldspar porphyroclasts [Grasemann and Petrakakis, 2007; Grasemann et al., 2012]. 


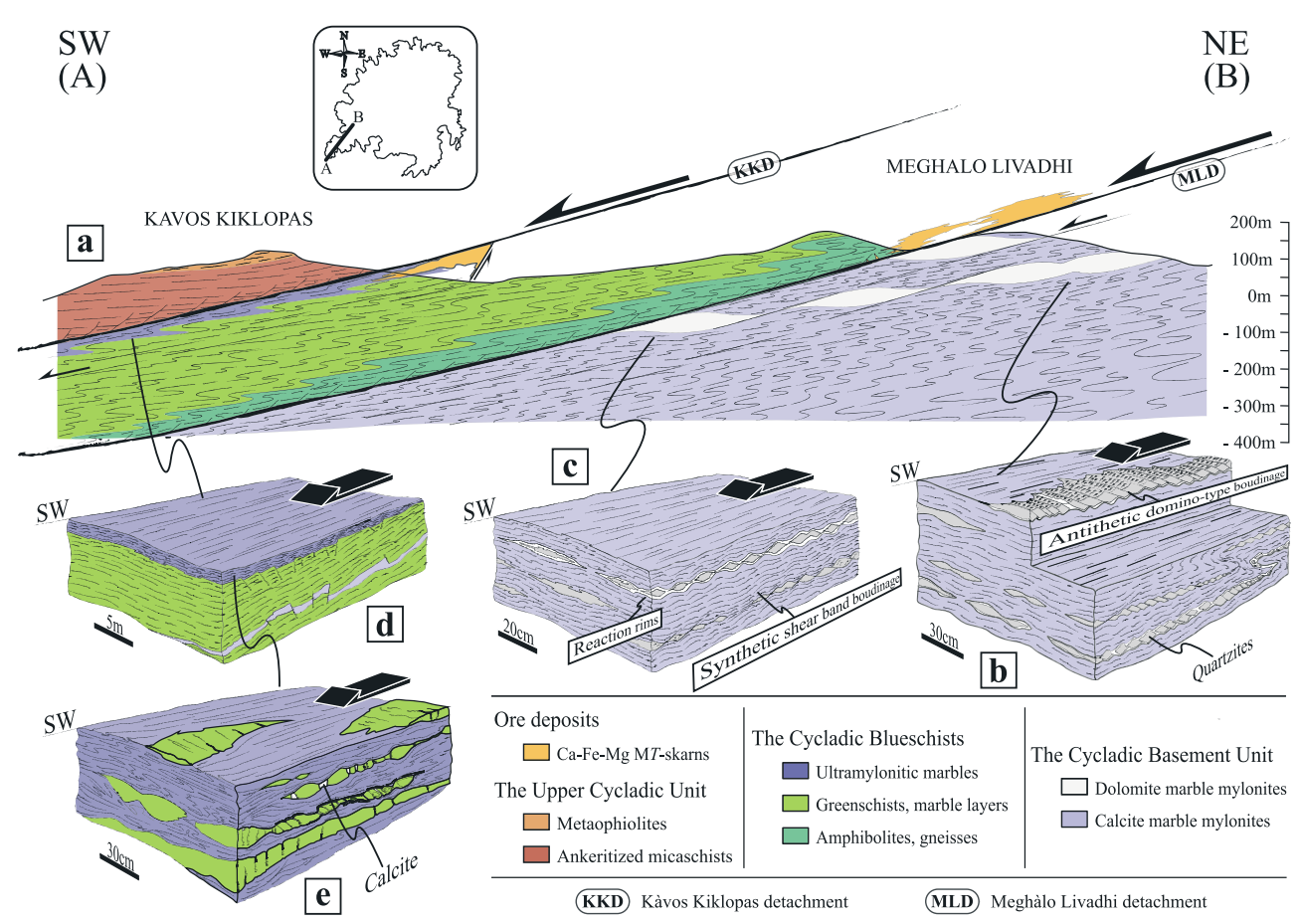

Figure 2. (a) Structural cross section of the southwestern part of Serifos Island oriented parallel to the stretching direction (A-B, location in the map inset at upper left). This cross section shows the Meghàlo Livadhi detachment and the Kàvos Kiklopas detachment that separate the Cycladic Basement Unit from the Cycladic Blueschists and the Cycladic Blueschists from the Upper Cycladic Unit, respectively. They display similar NE-SW oriented stretching lineation and SW directed shear sense. Extensional shearing is associated with Ca-Fe-Mg MT skarns that involve hydrothermal circulation of fluids during intrusion and cooling of the granodiorite. (b-e) The 3-D block diagrams illustrating field structures related to the stable top-to-the-SW shearing below each detachment (see text for further explanations).

About $30 \mathrm{~m}$ below the Meghàlo Livadhi detachment, a conspicuous top-to-the-SW shearing overprints the earlier top-to-the-W ductile deformation. An overall southwestward and upward strain gradient can be observed, suggesting the presence of a SW directed crustal-scale shear zone as described by Grasemann and Petrakakis [2007] and Grasemann and Tschegg [2012]. Quartzites intercalated with dolomite-calcite marble mylonites show an intense boudinage developed under a southwest directed shearing (see 3-D block diagrams in Figures $2 \mathrm{~b}$ and $2 \mathrm{c}$ ), revealed by asymmetric shapes of boudins evolving from antithetic domino-type to synthetic shear band boudinage, and ultimately complete dismembering (classification and terminology after Goscombe et al. [2004]). The earlier W to WSW oriented mylonitic lineation can still be recognized directly on the foliation surface of boudins [Grasemann and Tschegg, 2012]. The boudinage of quartzite layers is often associated with reaction rims and the growth of talc-tremolite and calcite. These reaction rims thicken in the vicinity of the detachment [Grasemann and Tschegg, 2012], suggesting fluid circulations. This hydrothermal activity is also recognized by Fe-Ba LT massive and veins deposits, within or perpendicular to the mylonitic foliation.

Toward Cape Psari Myti $\left(4112049^{\circ} \mathrm{N}, 274095^{\circ} \mathrm{E}\right.$; the GPS coordinates are given in universal time meridian (UTM) zone $35^{\circ} \mathrm{N}$, World Geodetic System (WGS) 1984) and Cape Platini $\left(4111487^{\circ} \mathrm{N}, 274363^{\circ} \mathrm{E}\right)$, the CBU crops out; it consists of gneisses with mylonitic marble intercalations and metabasites dipping gently to the SW. A clear stretching lineation trends southwestward with macroscale evidence for top-to-the-SW sense of shear. Sheath folds with NE-SW axes are preserved within mylonitic marbles (Figure 3c). Metabasites with gneissic intercalations retrogressed under greenschist conditions reveal grains of biotite with fish-like geometries suggesting a consistent top-to-the-SW sense of shear.

The hanging wall of the Meghàlo Livadhi detachment, consisting of amphibolites, shows an extensional deformation that is recognized as a thick zone of cataclastic deformation and high-angle normal faults, indicating a NE-SW direction of extension (Figure 3d), consistent with shearing of the footwall. Cataclastic amphibolites belonging to the Cycladic Blueschists have also been affected by an intense fluid circulation 

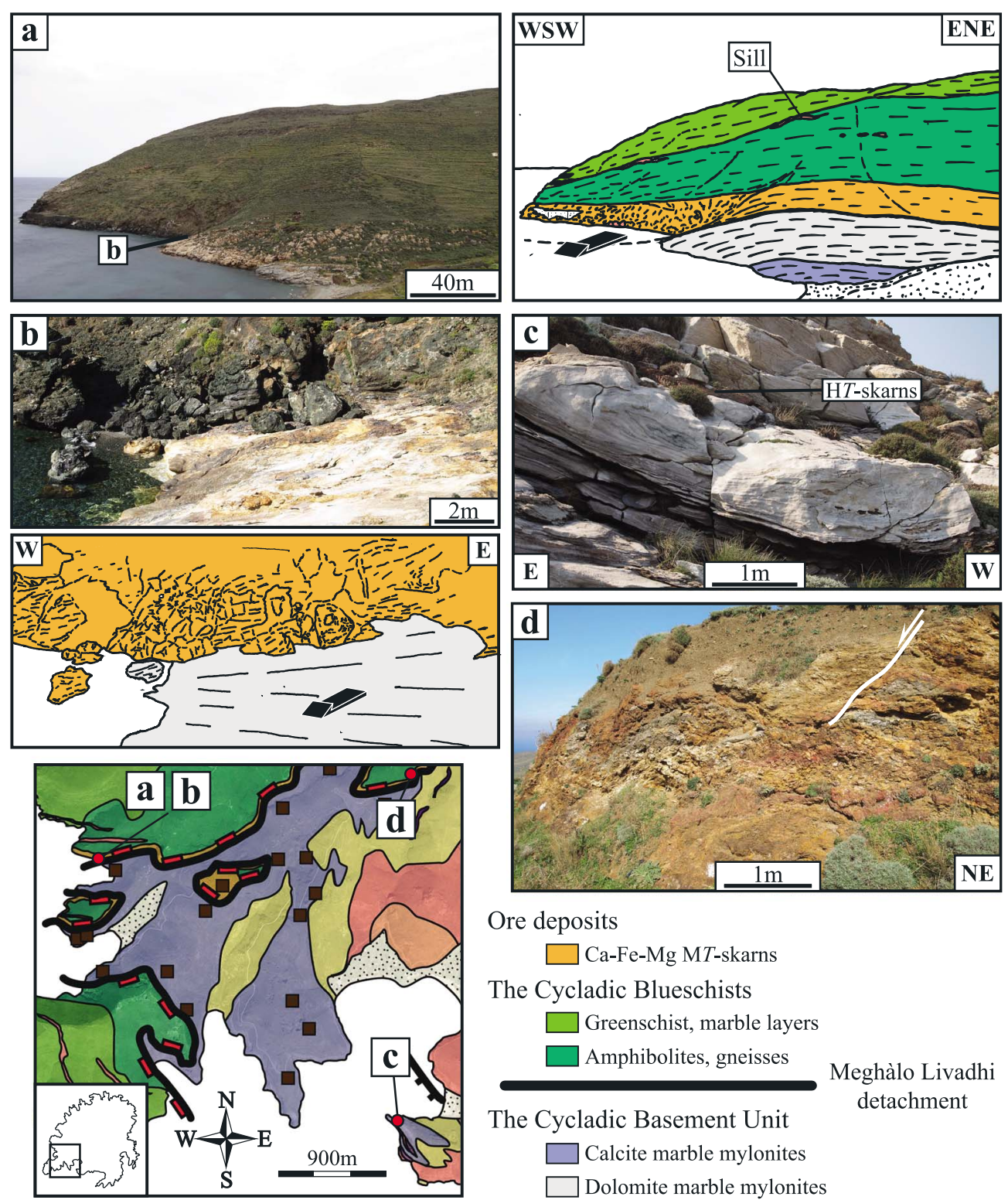

Ore deposits

$\square$ Ca-Fe-Mg MT-skarns

The Cycladic Blueschists

\section{$\square$ Greenschist, marble layers \\ Amphibolites, gneisses}

The Cycladic Basement Unit

$\square$ Calcite marble mylonites

Dolomite marble mylonites

Figure 3. Photographs related to the lowermost Meghàlo Livadhi detachment in southwestern Serifos (locations in the map inset at lower left). (a) View of the west dipping detachment that separates greenschists and amphibolites in the hanging wall from marble mylonites in the footwall. Amphibolites have been affected by fluid circulation evidenced by $30 \mathrm{~m}$ thick zone of Ca-Fe-Mg MT skarns. Mafic and granodioritic sills outcrop in the hanging wall of the Meghàlo Livadhi detachment. (b) View of the Meghàlo Livadhi detachment plane. (c) Sheath folds with NE-SW axe within mylonitic marbles near Cape Psari Myti. (d) Cataclastic deformation and high-angle normal faults indicating a NE-SW direction of extension.

evidenced by $30 \mathrm{~m}$ thick zone of breccia-hosted ore deposits composed mainly of hedenbergite, ilvaite, calcite, and quartz (Figures 3a and 3b). These Ca-Fe-Mg MT-exoskarns correspond to a regional level associated to the Meghàlo Livadhi detachment. Interestingly, several mafic and granodioritic sills crop out throughout the southwestern part of Serifos Island (Figure 3a), especially in the hanging wall of the Meghàlo Livadhi detachment.

\subsubsection{Kéntarchos and Panagia Areas}

The basal amphibolites-gneisses sequence belonging to the Cycladic Blueschists locally recorded a continuum of deformation from ductile to brittle conditions (Figure 4a). Succession of deformation events was kinematically compatible with the development of the Meghàlo Livadhi detachment. Near Kéntarchos village $\left(4118317^{\circ} \mathrm{N}, 279447^{\circ} \mathrm{E}\right)$, one can indeed recognize intense folding defined by NW-SE fold axes 

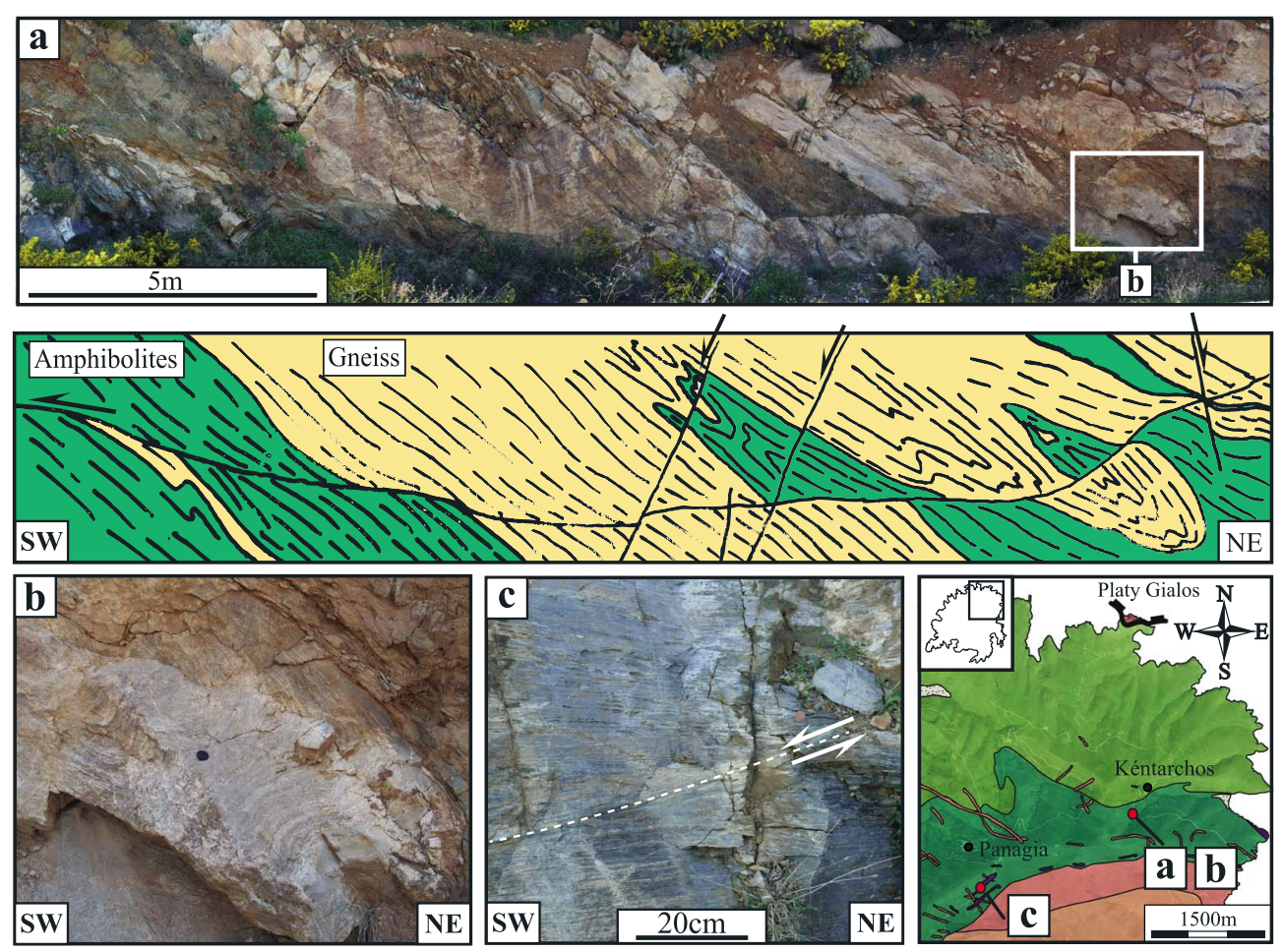

Figure 4. Photographs of deformation and associated kinematic indicators in the basal amphibolites-gneisses sequence belonging to the Cycladic Blueschists (locations in the map inset at lower right). (a) NE-SW deformation events with a continuum from ductile to brittle conditions. (b) Folding of gneisses defined by NW-SE fold axes. (c) Shear band with a top-to-the-SW sense of shear.

(Figure 4b), overprinted by gently NE dipping ductile/brittle shear zones. Kinematic indicators indicate a topto-the-SW shear sense. Continuum of deformation finally evolved to a brittle regime evidenced by a system of conjugate high-angle normal faults, consistent with NE-SW oriented extension.

At deeper structural level, toward the contact with the pluton (Panagia area, $4117548^{\circ} \mathrm{N}, 277015^{\circ} \mathrm{E}$ ), wellpreserved ductile deformation has been observed. Gneissic intercalations with amphibolites were intensely deformed with a coaxial component. Mylonitic foliation dips gently northward and carries a NE-SW stretching lineation. Meter-scale shear bands reveal a top-to-the-SW sense of shear (Figure 4c).

\subsection{Kàvos Kiklopas Detachment}

\subsubsection{Southwestern Part of Serifos Island}

The uppermost branch of the low-angle normal fault system crops out around Kàvos Kiklopas Peninsula (Figures $1 \mathrm{~b}$ and 2a). The Kàvos Kiklopas detachment dips $10^{\circ}$ westward and separates marbles and micaschists in the footwall from cataclastic ankeritized micaschists in the hanging wall (Figure 5a). A few meter thick mylonitized marbles belonging to the Cycladic Blueschists crop out directly below the lowangle normal fault and record an intense top-to-the-SW shearing, consistent with the kinematics of Meghàlo Livadhi detachment (see 3-D block diagrams in Figures $2 \mathrm{~d}$ and 2e). The greenschists alternating with ultramylonitic marbles were folded, boudinaged, and truncated into isolated fragments (Figure $5 \mathrm{~b}$ and 3-D block diagram in Figure 2e). Brittle fracturing, only observed in the greenschists, provides evidence of rheological contrast between micaschists and alternating marbles, which are more ductile. Metapelites with marble intercalations occur structurally below the ultramylonitic marbles (Figure 5a). Metamorphic rocks underwent retrograde metamorphism under greenschist-facies conditions and record a top-to-the-WSW shear sense as revealed by shear bands. Locally, the footwall was reworked by brittle high-angle normal faults indicating a late brittle increment of extensional deformation (Figures $5 a$ and $5 b$ ).

Extension in the footwall was thereby accommodated by a localized ductile/brittle deformation supported by few meters thick ultramylonitic marbles associated with top-to-the-SW shear sense, whereas rocks of the hanging wall accommodated extension along high-angle normal faults. Near the southernmost tip of 

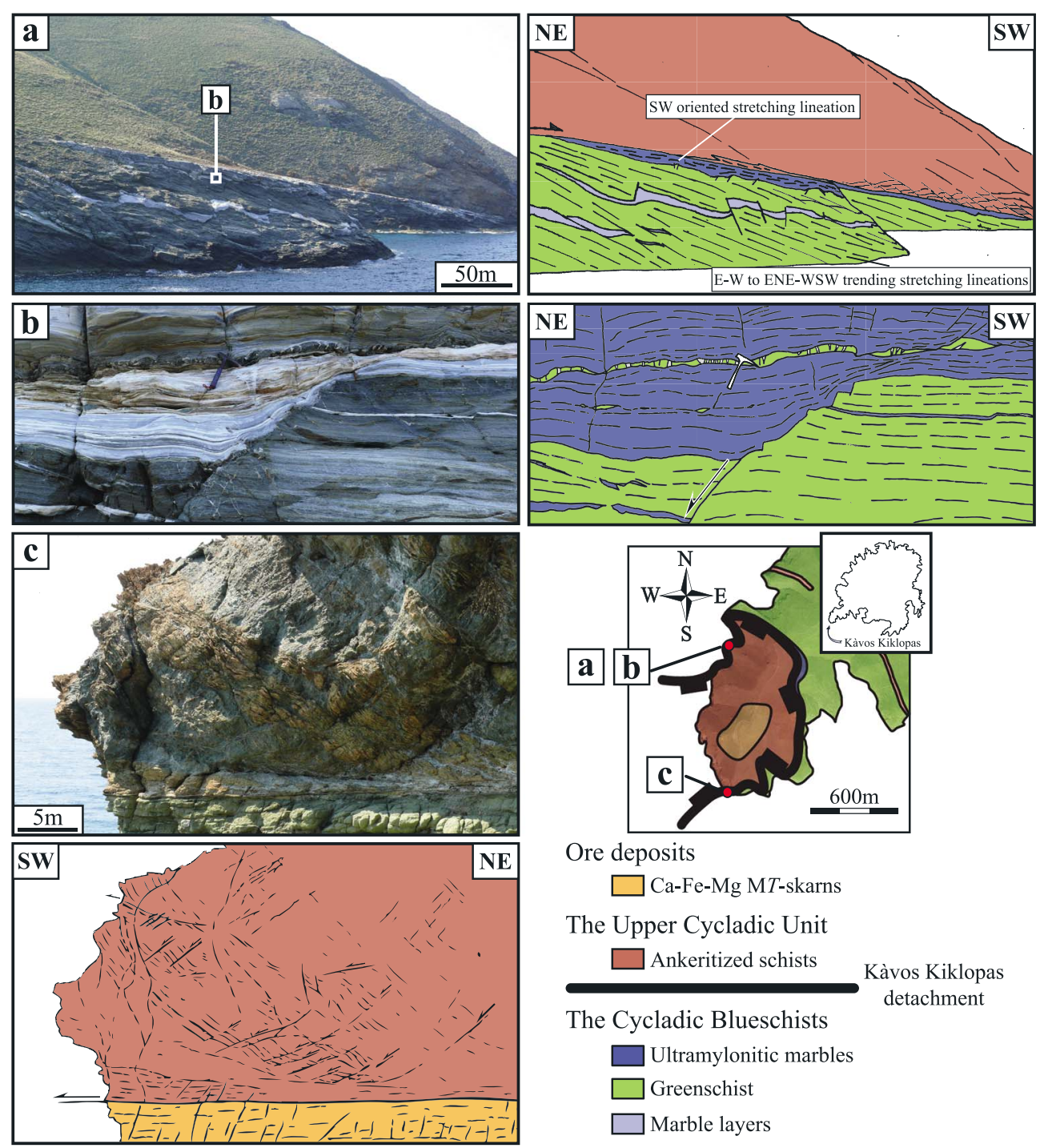

Ore deposits

$$
\square \text { Ca-Fe-Mg MT-skarns }
$$

The Upper Cycladic Unit

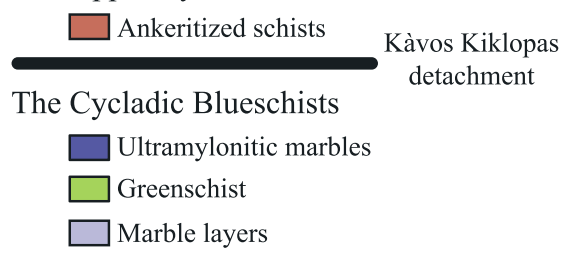

Figure 5. Photographs of the uppermost Kàvos Kiklopas detachment in southwestern Serifos (locations in the map inset at lower right). (a) View of the west dipping detachment that separates marbles and micaschists in the footwall from cataclastic ankeritized schists in the hanging wall. (b) Greenschists with mylonitized marbles just below the Kàvos Kiklopas detachment. (c) View of the Kàvos Kiklopas detachment. Brittle deformation affects ankeritized micaschists belonging to the hanging wall (the Upper Cycladic Unit) with NE-SW extension and a southwest directed displacement.

Kàvos Kiklopas Peninsula, a decametric thick zone of ultracataclasites and protocataclasites has developed directly above the detachment (Figure $5 \mathrm{c}$ ). Brittle deformation affected ankeritized micaschists belonging to the Upper Cycladic Unit showing a NE-SW extension and a SW directed displacement, compatible with brittle/ductile deformation in the footwall. The ankeritized micaschists are overlain by altered serpentinites and talc-schists that dip gently $10^{\circ}-15^{\circ}$.

\subsubsection{Northeastern Part of Serifos Island}

The Kàvos Kiklopas detachment between the Cycladic Blueschists and the Upper Cycladic Unit crops out around Platy Gialos Peninsula in the northeasternmost part of Serifos, showing a well-exposed section of this brittle-ductile low-angle normal fault dipping $12^{\circ}-15^{\circ}$ northeastward.

The footwall consists mainly of greenschists/calcschists with metaconglomerate intercalations and ultramylonitic marbles at the top of the unit, similar to the southern outcrops. Approaching the detachment, the whole sequence records a gradient in shearing as well as a progressive rotation of the stretching direction. At deeper structural level, carbonate stretched pebbles in a metaconglomerate show a 

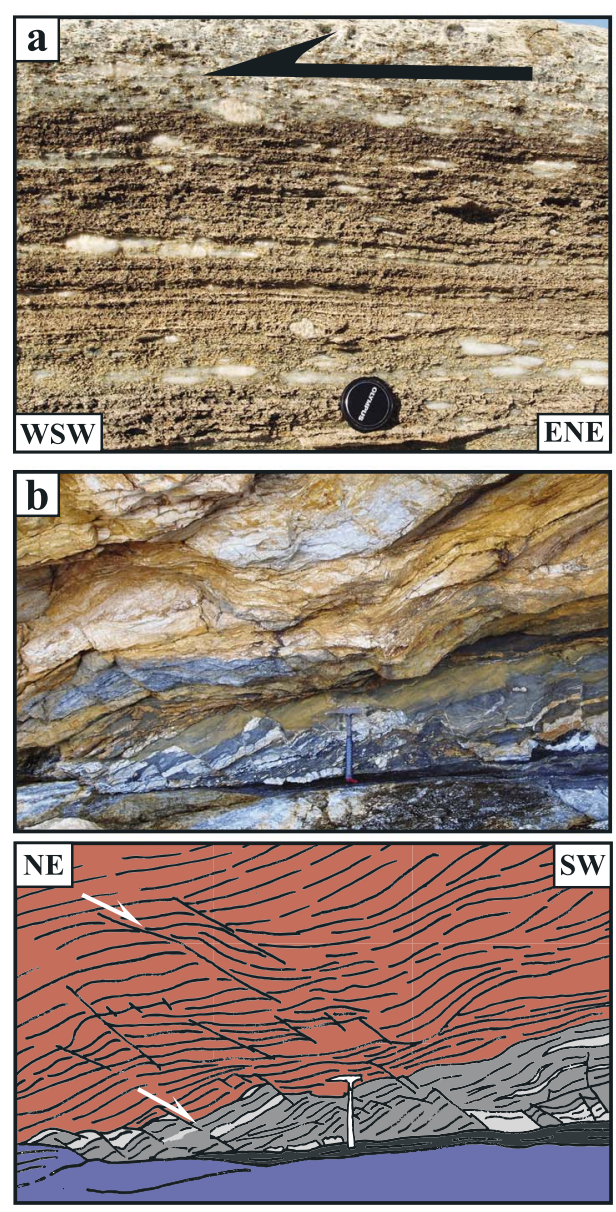

\section{政}

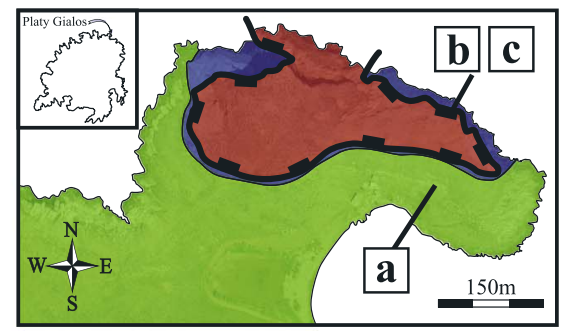

The Upper Cycladic Unit

$\square$ Calcschists

$\square$ Ultracataclasites of marbles

$\square$ Ultracataclasites of graphitic schists

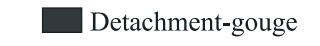

The Cycladic Blueschists

Kàvos Kiklopas detachment

$\square$ Ultramylonitic marbles

Metapelites with metaconglomerates
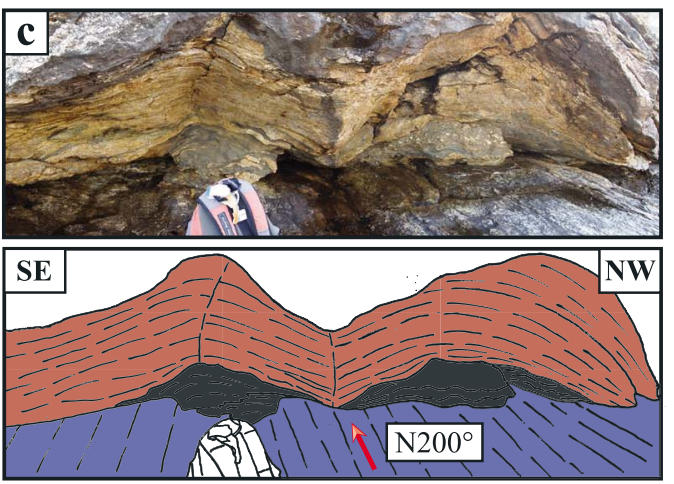

Figure 6. Kàvos Kiklopas detachment in northeastern Serifos (Platy Gialos peninsula; location in the map inset at upper right). The footwall consists of metapelites with metaconglomerate intercalations and ultramylonitic marbles at the top of the unit (the Cycladic Blueschists). The hanging wall consists of calcschists belonging to the Upper Cycladic Unit. (a) Carbonate stretched pebbles in a metaconglomerate showing a top-to-the-WSW shear sense. (b) Thick zone of cataclasites in the hanging wall with SW directed displacement. (c) View of the Kàvos Kiklopas detachment plane showing a NE-SW striation parallel to the stretching lineation in the underlying ultramylonitic marbles.

prolate shape with an E-W long axis, evolving toward a conspicuous ENE-WSW trending lineation and a subsequent striation toward the brittle detachment plane. Kinematic indicators show a top-to-the-WSW shear sense (Figure 6a). Directly below the detachment plane, a few meters thick ultramylonitic marbles are observed (Figures $6 \mathrm{~b}$ and $6 \mathrm{c}$ ); they show intense intrafolial folding and a SW-NE oriented stretching lineation.

These ultramylonitic marbles are separated from a thick zone of cataclasites by a low-angle normal fault (Figures $6 \mathrm{~b}$ and $6 \mathrm{c}$ ). Outcrops of the detachment plane show an intense striation parallel to the stretching lineation in the underlying ultramylonitic marbles (Figure $6 \mathrm{c}$ ). The detachment plane is overlain by a centimeter thick of detachment gouge and ultracataclasites of graphitic schists, marbles, and calcschists (Figure 6b). The whole sequence belonging to the Upper Cycladic Unit records brittle extensional structures with SW directed displacement, consistent with the brittle-ductile deformation of the ultramylonitic marbles. Furthermore, both hanging wall and footwall record a component of subhorizontal shortening, perpendicular to the shearing direction, resulting in box-shaped folding of the penetrative fabric (Figure 6c).

\section{Field Observations in the Serifos Granodiorite}

\subsection{Mesoscopic Fabrics and Field Structures}

In order to characterize the mesoscopic fabric pattern of the Serifos granodiorite and the kinematic of its deformation, we performed a detailed structural fieldwork. Fabric is usually well developed in the 

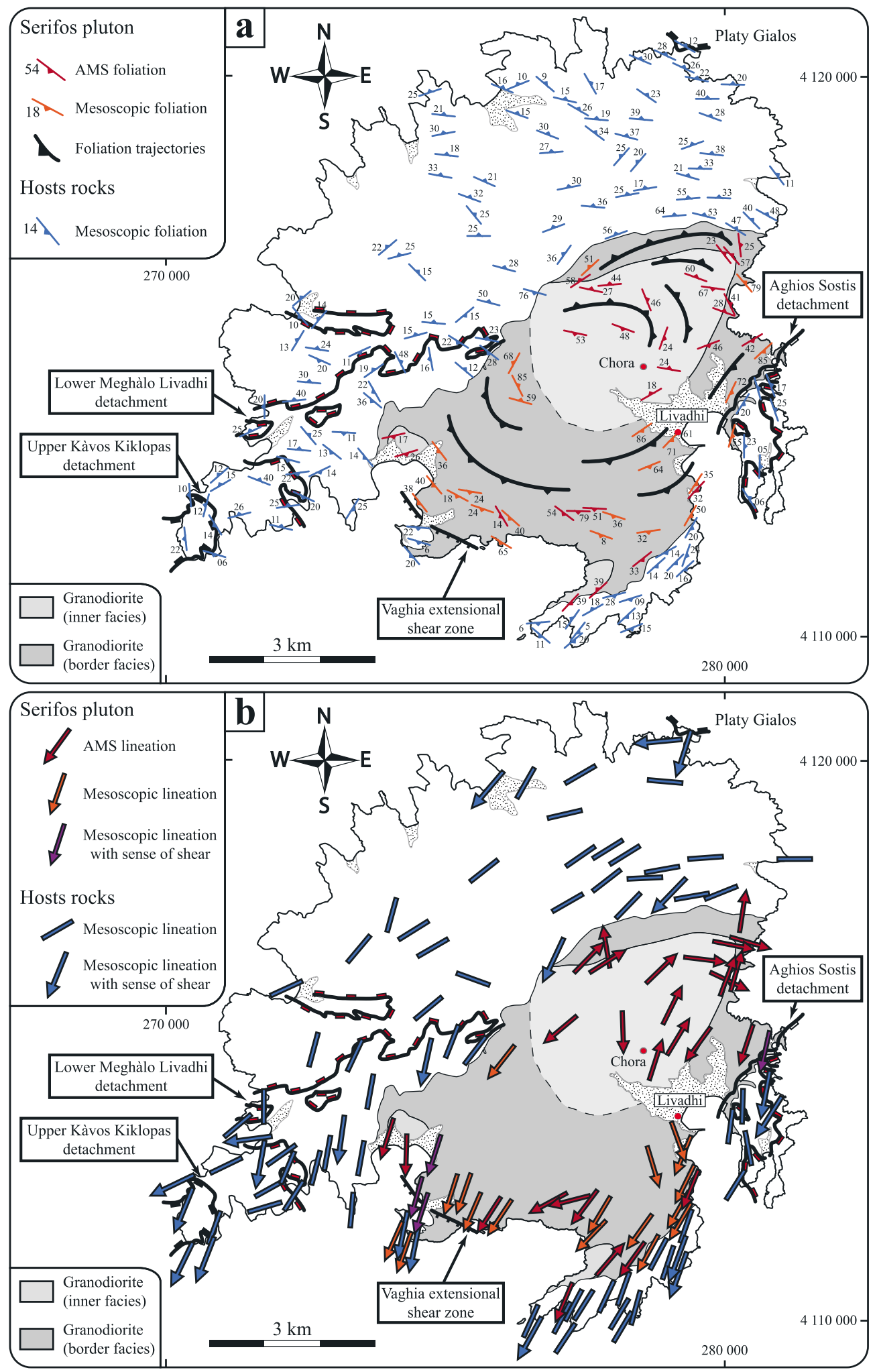

Figure 7. Structure and finite strain maps of the studied area. (a) AMS foliations and mesoscopic foliations. (b) AMS lineations and mesoscopic lineations. 

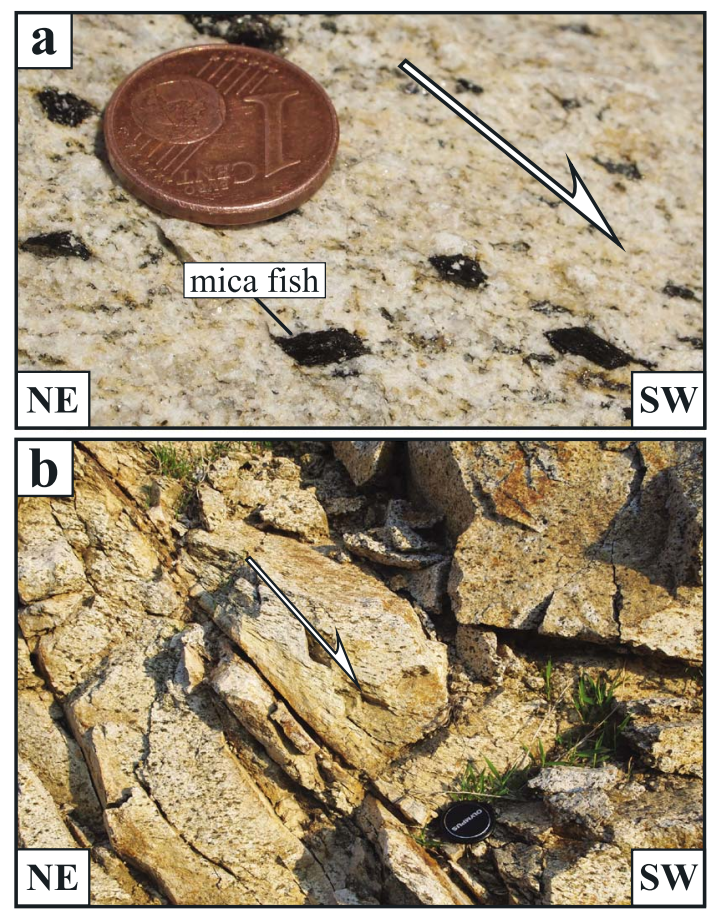

Figure 8. Photographs showing structural observations in the southwestern margin of Serifos pluton (border facies). (a) Development of mica fish with top-to-the-SW shearing $\left(4112280.66^{\circ} \mathrm{N}, 274603.87^{\circ} \mathrm{E}\right)$. (b) Ductile/brittle high-angle normal fault $\left(4113557.64^{\circ} \mathrm{N}, 274771.51^{\circ} \mathrm{E}\right)$. southwestern and eastern border facies, whereas the northern border facies and the inner facies reveal either a weak or indiscernible mesoscopic fabric. Importantly, transitions between these facies are gradational, and no sharp contact was observed. Foliation is defined by the shapepreferred orientation of biotite flakes. Orientation of the lineation trajectories is based on the measurements of elongation of amphibole grains. Our own measurements of foliation and associated lineations are presented in Figures $7 \mathrm{a}$ and $7 \mathrm{~b}$.

\subsubsection{Southern Margin}

The border facies outcropping in the southern contact of the intrusive body reveals a strongly prolate fabric. Even if foliation is difficult to discern macroscopically, biotite flakes dip very gently $10^{\circ}-15^{\circ}$ southeastward and strike NE-SW, roughly parallel to the pluton margin (Figure 7a). When amphibole can be distinguished, the lineation is marked by the direction of its $[c]$ axis, and it trends southwest-

northeast (Figure 7b). Interestingly, the fabric becomes steeper northward $\left(60^{\circ}\right.$ to $\left.85^{\circ}\right)$ with subvertical lineations, especially in the sector of Chora/Livadhi (Figures 7a and 7b).

\subsubsection{Southwestern Margin}

In Koutalas-Vaghia Bay (Figures $1 \mathrm{~b}$ and 7), the border facies exhibits an apparent stronger fabric than the southern margin of the pluton. As described in the southern margin, the border facies displays an oblate fabric (Figures $7 \mathrm{a}$ and $7 \mathrm{~b}$ ). While foliation is more easily discernible and dips $20^{\circ}-40^{\circ}$ southwestward, lineation outlined by amphibole grains plunges systematically $20^{\circ}-30^{\circ}$ southwestward. Close to the contact with host rocks, the border facies was affected by the development of an extensional shear zone that partially overprinted the earlier SL fabric. Field observations show a widespread consistent NE-SW direction of stretching. Evidence of ductile deformation and top-to-the-southwest shearing is especially provided by the development of mica fish (classification and terminology after Lister and Snoke [1984], ten Grotenhuis et al. [2003], and Mukherjee [2010]) (Figure 8a; $\left.4112280.66^{\circ} \mathrm{N}, 274603.87^{\circ} \mathrm{E}\right)$. Furthermore, the southwestern pluton was affected by a network of ductile/brittle high-angle normal faults showing NE-SW oriented extension (Figure $8 \mathrm{~b} ; 4113557.64^{\circ} \mathrm{N}, 274771.51^{\circ} \mathrm{E}$ ).

\subsubsection{Eastern Margin}

The apparent strongest deformation was recorded at the eastern margin of the Serifos pluton, toward Aghios Sostis Peninsula (Figures 1b, 7a, and 7b). This zone corresponds to the development of a SE dipping low-angle normal fault that separates ultramylonitic granodiorite in the footwall from strongly bleached granodiorite in the hanging wall, as described by Grasemann and Petrakakis [2007] and Tschegg and Grasemann [2009].

The footwall records a southeastward and upward gradient of shearing, suggesting the presence of a ductile shear zone. Particularly, mesoscopic observations show a progressive transition from weakly deformed granodiorite at deeper structural level to an ultramylonitic fabric in the vicinity of the detachment. A conspicuous stretching lineation trends to the southwest in the whole sequence. $\mathrm{SC}^{\prime}$ fabric, mica fish clasts, and "tiling" of biotite flakes indicate homogeneously a top-to-the-SW sense of shear. Furthermore, up to decimeter thick synthetic and antithetic shear bands separating ultramylonitic granodiorite from less strongly deformed granodiorite can be also observed. This anastomosing network of ductile shear 
bands nucleated along brittle precursor joints indicates a top-to-the-SW sense of shear [Tschegg and Grasemann, 2009].

Structural field observations provide a gradual change of foliation directions within structurally deeper granodiorite. Approaching the detachment, the SL fabric evolves from steeply W dipping foliation to gently SE dipping foliation, which is consistent with a top-to-the-SW sense of shear. However, at the deepest structural level, the shape-preferred orientation of biotite defines a weak foliation steeply dipping to the SSE, suggesting an S fabric apparently incompatible with the top-to-the SW shear sense. This fabric could thus correspond to an earlier fabric, partially preserved since shear zone nucleation.

The hanging wall granodiorite above the detachment recorded completely different metamorphic, structural, and geochemical evolution (for more details, see Tschegg and Grasemann [2009]). This granodiorite recorded a weak deformation under greenschist facies and was strongly bleached reflecting metasomatic-hydrothermal activity. The Aghios Sostis Peninsula was then crosscut by a NW-SE striking, high-angle normal fault, indicating ongoing NE-SW oriented extension.

\subsection{Enclaves and Synplutonic Dikes}

The Serifos granodiorite, especially the border facies, contains abundant enclaves and synplutonic dikes. On the basis of field observations, one can distinguish isolated enclaves, monogenic/polygenic swarms of enclaves, dike-like monogenic swarms, and undisturbed or partially disaggregated dikes. Isolated enclaves will not be described in this study.

\subsubsection{Swarms of Enclaves}

Monogenic swarms are mainly disseminated throughout the southern margin of the Serifos pluton. The term "swarm" is used to describe areas in the intrusion where enclaves are most abundant and are separated by the minimal amount of host material. In the field, variable sizes of enclaves occur, cropping out from decimeter size to decameter size. Their shapes display a wide range of morphologies, most frequently tapered but sometimes angular. Contacts with the host granodiorite are commonly lobate (Figures 9a), suggesting a relatively low viscosity contrast among the involved magmas [e.g., Sparks and Marshall, 1986; Vernon et al., 1988; Tobisch et al., 1997; Paterson et al., 2004; Barbarin, 2005]. Moreover, mineral fabric of enclaves appears systematically subparallel to principal fabric within the granodiorite, trending $\mathrm{N} 20^{\circ}$ to $\mathrm{N} 30^{\circ}$ (Figure 9a). At some localities, polygenic swarms of enclaves are exposed. The best representative example is located at Koutalas-Vaghia Bay, where the footwall of a sill intruding the host mylonitic marble contains a polygenic swarm $\left(4111848.86^{\circ} \mathrm{N}, 274196.41^{\circ} \mathrm{E}\right)$. Enclaves mostly have diffuse contacts and consist of dioritic enclaves and melanocratic to mesocratic enclaves. They have either ellipsoidal or random shapes and are often elongated parallel to the NE-SW stretching direction observed in the granodiorite.

\subsubsection{Synplutonic Dikes}

Synplutonic dikes have been especially observed at the pluton rim where all the intermediate stages between undisturbed dikes and dike-like monogenic swarms are found:

The southernmost granodiorite was abundantly intruded by undisturbed mafic/felsic dikes, particularly extensive sets of leucocratic/dioritic dikes crosscutting swarms of enclaves (Figures 9a). Contacts between these dikes and the enclosing granodiorite remain sharp and straight. Toward Koutalas-Vaghia Bay, where an extensional shear zone has developed, NW-SE to WNW-ESE trending dioritic/aplitic dikes are sometimes affected by antithetic top-to-the-SW shearing (Figure $9 \mathrm{~b} ; 4113360.04^{\circ} \mathrm{N}, 274884.10^{\circ} \mathrm{E}$ ). On the other hand, in the northern pluton margin, some dioritic/aplitic dikes crosscut the marginal coarse-grained facies that follow roughly NW-SE striking brittle high-angle normal faults (Figure 9c).

Dike-like monogenic swarms of enclaves crop out near Vaghia Bay $\left(4112308.43^{\circ} \mathrm{N}, 274586.41^{\circ} \mathrm{E}\right)$. This sector shows swarms that resemble disaggregated mafic dikes within partially crystallized host magma. The dikelike monogenic swarms are a few tens of meters wide with commonly rectilinear borders.

Among synplutonic dikes, some of them have locally fine-grained disaggregated margins where thermal contrasts between the two magmas appear relatively weak. An outcrop to the east of Rammos village reflects an interesting example of a partially disaggregated synplutonic dike. This NW-SE striking mafic dike, a few meters wide, has intruded vertically the granodioritic host rock (Figure 9d). Its margins show heterogeneous mingling. Its northeastern margin display lobate contacts with the enclosing host 


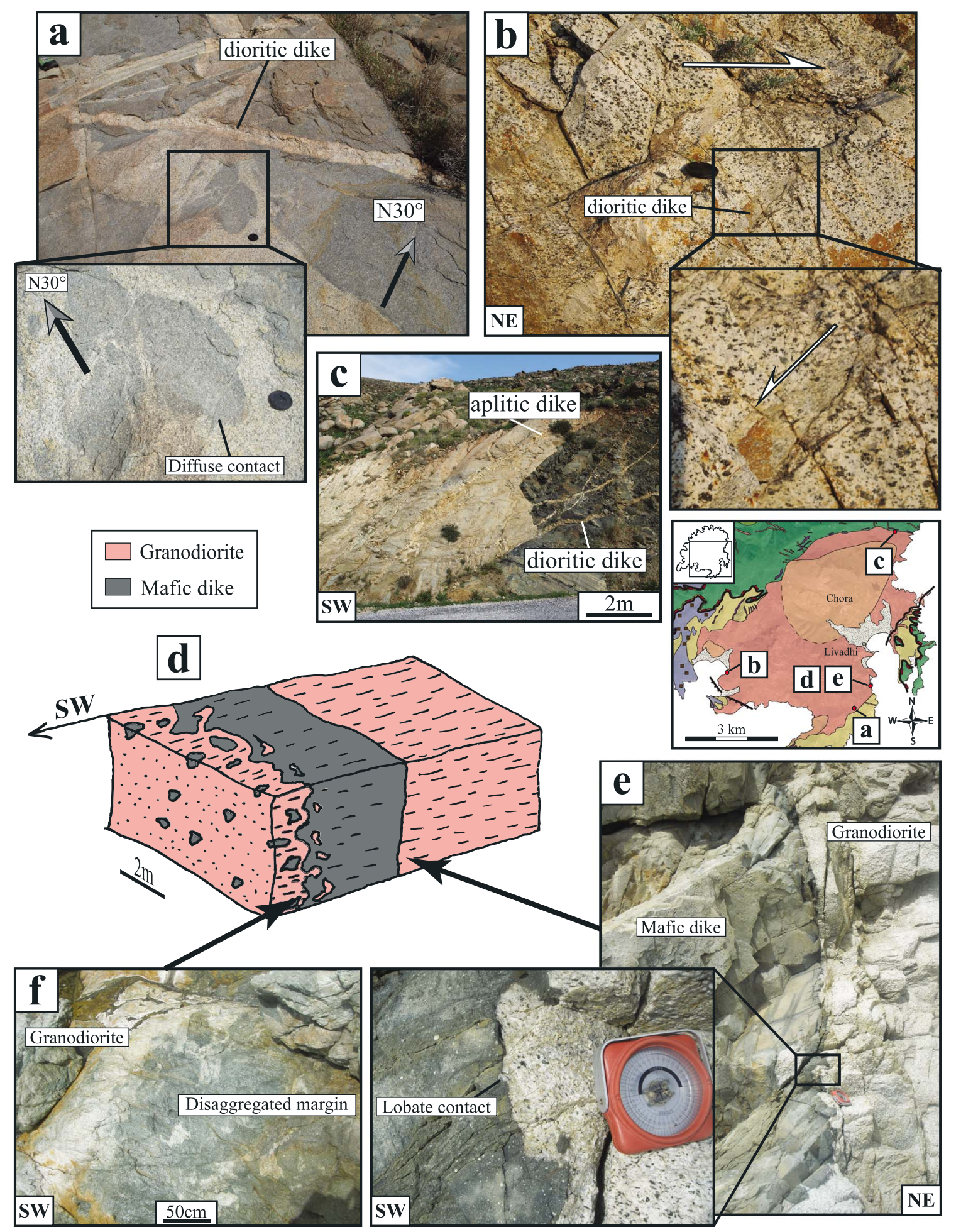

Figure 9. Photographs and 3-D block diagram of swarms of enclaves and synplutonic dikes. (a) Example of Monogenic swarm located at the southern rim. Note that mineral fabrics of enclaves are subparallel to the host granodiorite fabric. Dioritic dikes crosscutting swarm can also be observed. (b) NW-SE striking dioritic dike affected by an antithetic top-to-the-SW shearing $\left(4113360.04^{\circ} \mathrm{N}, 274884.10^{\circ} \mathrm{E}\right)$. (c) Intrusive contact with host rocks at the northeastern part. Note that dioritic/ aplitic dikes have the same orientation as NW-SE striking brittle high-angle normal faults. (d) The 3-D block diagram showing a vertical partially disaggregated mafic dike; its margins are submitted to heterogeneous mingling. (e) Northeastern margin of the partially disaggregated mafic dike. (f) Southwestern margin of the partially disaggregated mafic dike. 

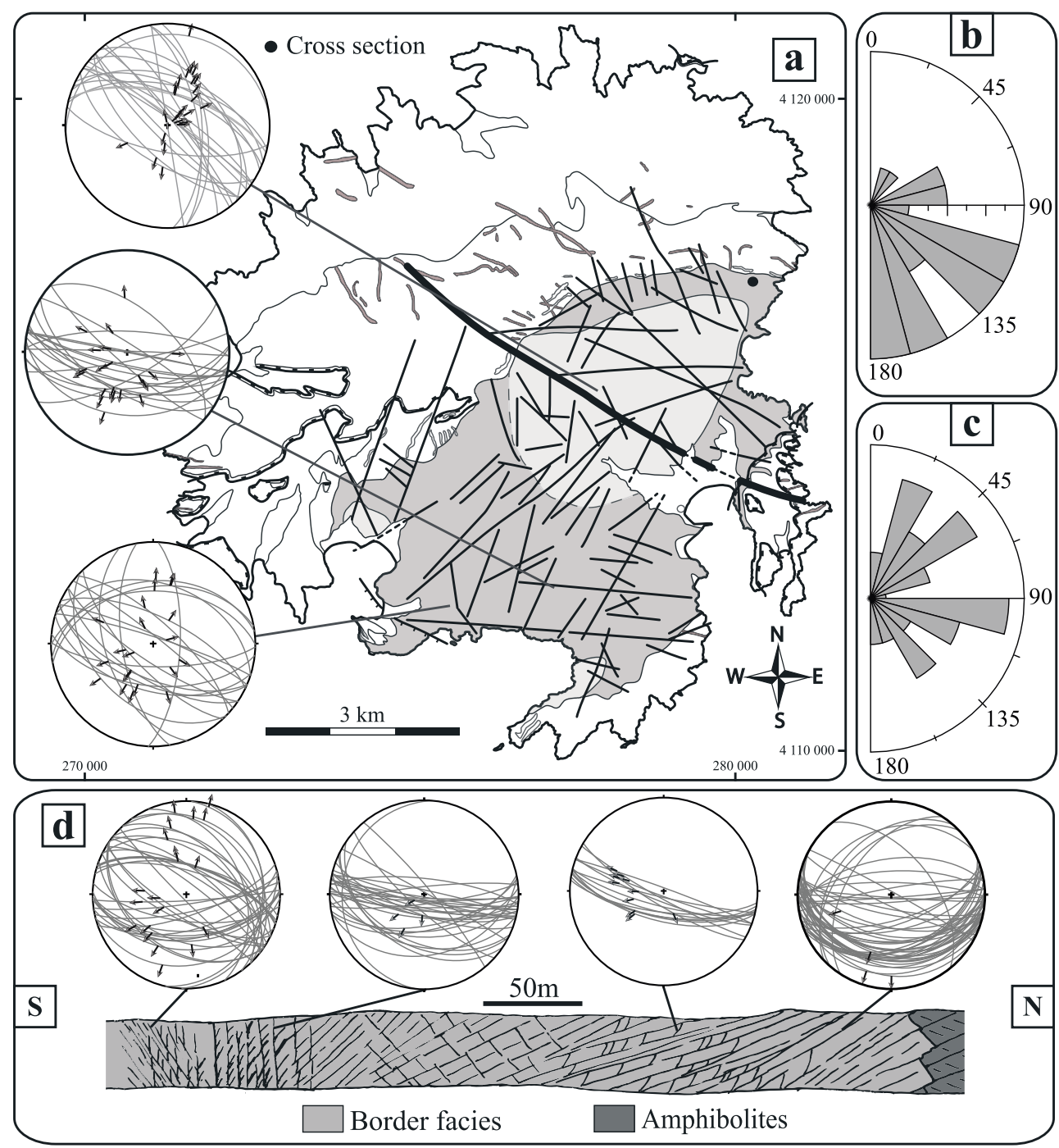

Figure 10. Brittle structures in Serifos pluton. (a) Tectonic map showing steep fractures (modified after Lambrakis et al. [2000]) with stereonets of macroscale fault planes and their kinematic indicators. (b and c) Stereonets showing two sets of fractures. (d) Cross section in northeastern Serifos margin showing typical fracture systems observed in this sector.

granodiorite (Figure 9e), whereas its southwestern margin is disaggregated in enclaves formed by synmagmatic mingling (Figure 9f).

\subsection{Late Brittle Structures}

Structural fieldwork allowed us to identify the geometry of the fault network and associated kinematics. Measurements of small-scale fault planes and their kinematic indicators were carried out at several sites of the granodiorite (Figure 10a). At map scale, this study indicates that Serifos granodiorite is predominantly dominated by sets of WNW-ESE striking conjugate high-angle normal faults. Measured striae indicate a NE-SW component of extension.

Furthermore, the Serifos granodiorite is crosscut by a network of fractures, previously well documented by Lambrakis et al. [2000]. At map scale, two sets of fractures can be distinguished (Figure 10a). NW striking fractures mostly crosscut the northeastern part (Figure 10b), whereas the southwestern part of Serifos granodiorite is mainly affected by NE-SW and E-W striking fractures (Figure 10c). These two sets of fractures are spatially divided by a major kilometer-scale length brittle structure which trends NW-SE. In detail, this major brittle structure contains a considerable amount of spaced joint systems along which the granodiorite was completely bleached by fluid circulation. 

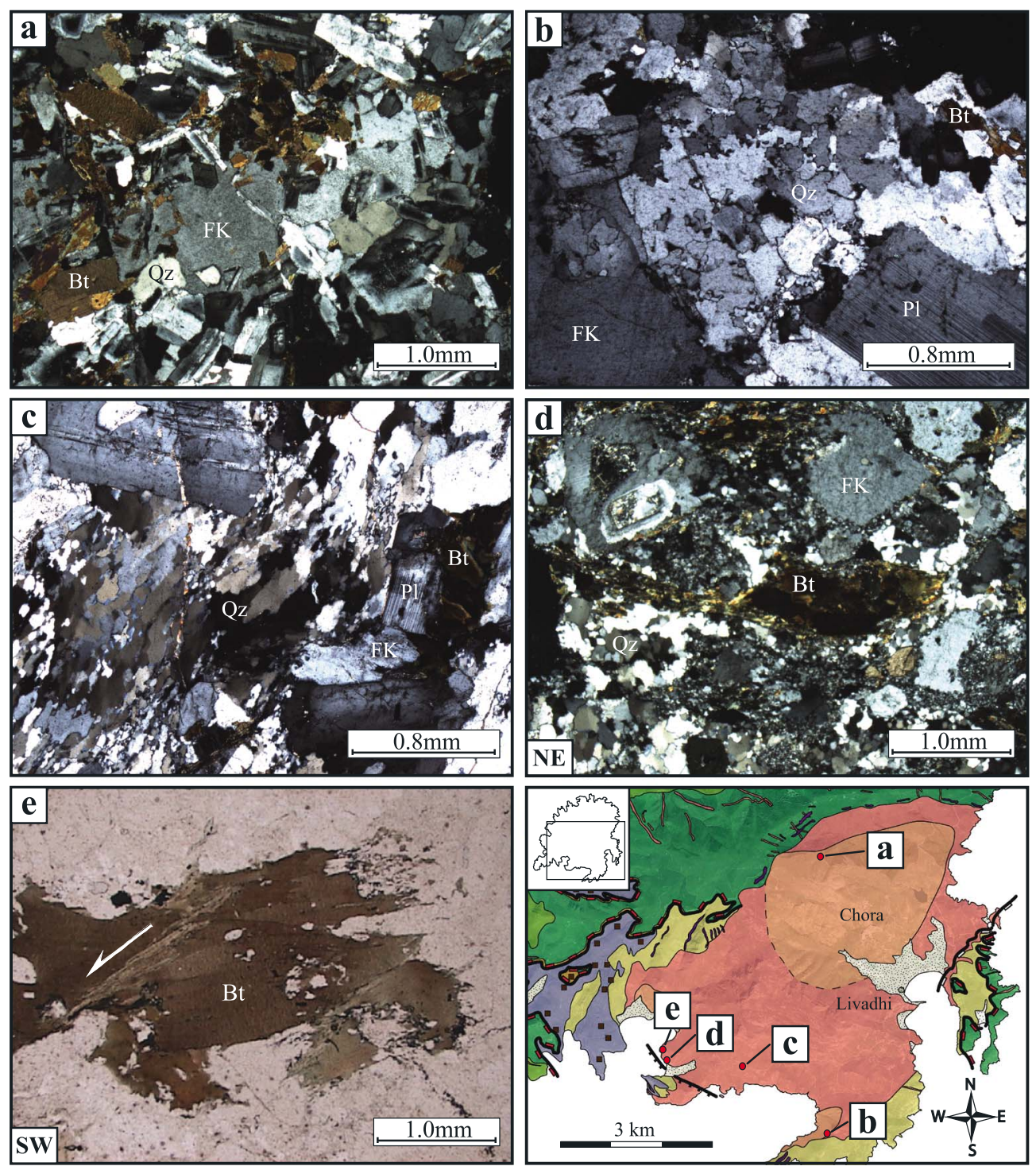

Figure 11. Microstructural features of typical investigated samples within the Serifos pluton (sample locations in the map inset at lower right), see explanation in the text for more details. $\mathrm{Bt}=$ biotite, $\mathrm{Kf}=\mathrm{K}$-feldspar, $\mathrm{PI}=\mathrm{Plagioclase}, \mathrm{Qz}=$ quartz.

Along the northern margin, several centimeter- to decimeter-sized fracture systems crosscuts the undeformed border facies of the granodiorite. Figure $10 \mathrm{~d}$ includes a cross section of typical fracture systems observed in this sector. Four kinds of fractures can thus be distinguished corresponding to either spaced joints or conjugate normal faults to dextral strike-slip faults along which fluids have bleached the magmatic rock in a zone of up to several centimeters wide. They are usually filled with chlorite, epidote, and carbonates. Even if some of them are steeply dipping and others are shallow dipping, their slickensides trend approximately NW-SE with NNE-SSW trending extensional component (Figure 10d).

\section{Microstructure and Anisotropy of Magnetic Anisotropy in the Serifos Granodiorite}

\subsection{Microstructural Observations}

Microstructural investigations within syntectonic plutons provide insights about the history of a continuous deformation developed during pluton cooling and its subsequent unroofing [Paterson et al., 1989]. This method also gives useful information as to how both mesoscopic and magnetic fabrics should be 
interpreted (see section 5.2 for AMS measurements). In this sense, a microstructural analysis was performed in some key outcrops of the Serifos granodiorite except along the Aghios Sostis detachment where a detailed microstructural study was already performed by Tschegg and Grasemann [2009]. Microstructural features of typical investigated samples are summarized in Figure 11.

In the northern and central parts of the Serifos pluton, both fine-grained and coarse-grained facies display magmatic microstructures without any significant solid-state overprint (Figure 11a). Mineral phases are usually uniformly dispersed, and some weak undulatory extinction in anhedral, interstitial quartz grains is quite common. Late brittle fracturing can be also observed, as in the whole pluton. At the southern margin of the plutonic body, a moderate-preferred orientation of biotite is observed. In thin sections, some biotite flakes appear to be undeformed, whereas others are slightly bent and/or locally kinked. Amphibole grains show scarce evidence of deformation, having sharp or slight undulose extinction. Quartz with undulatory extinction and irregular grain boundaries are commonly found, together with smaller independent new grains (Figure 11b). Approaching the southwestern margin, where an extensional shear zone has developed, microfabric intensity significantly increases. Bending, strong kinking, and recrystallization are particularly common in biotite flakes. Polycrystalline quartz aggregates with irregular grain boundaries recorded a widespread recrystallization by subgrain rotation or grain boundary migration (Figure 11c). K-feldspar and plagioclase grains locally display narrow recrystallized mantle. K-feldspar can also exhibit marginal replacement by myrmekite [Simpson and Wintsch, 1989; Vernon, 1991]. Toward Koutalas-Vaghia Bay, thin sections reveal a significant grain size reduction of all mineral phases (Figure 11d). Biotite is subjected to large ductile deformation and partial to complete transformation to aggregates. Mica fish are common and record consistently a top-to-the-SW sense of shear (Figure 11e). Nucleation and growth of new quartz and feldspar grains occur widely, visible in thin section, e.g., by the development of new finegrained feldspar around cores of old grains (Figure 11d).

\subsection{Anisotropy of Magnetic Susceptibility}

5.2.1. Methodology: Sampling and Measurements

Anisotropy of magnetic susceptibility (AMS) describes parameters of the magnetic susceptibility ellipsoid. Magnetic fabrics are then often used to complement structural data recorded in the field in weakly deformed rocks and in localities where no mesoscopic features are observed [e.g., Bouchez et al., 1990; Archanjo et al., 1994; Benn et al., 2001]. As the mesoscopic fabric is generally cryptic within the inner facies, we use AMS (for reviews and basic principles of the method, see, e.g., Borradaile and Henry [1997], Bouchez [2000], and Borradaile and Jackson [2010]) to reveal faint anisotropies in granodiorite subjected to imperceptible tectonic imprints. We also use AMS to compare with field data within the border facies.

A total of 28 sampling sites were drilled in the Serifos granodiorite: 15 sample sites in the inner facies and 13 in the border facies (see Figure $1 \mathrm{~b}$ for locations). At each site, 3 to 14 samples (cylinder-shaped cores) were analyzed. Anisotropy of magnetic susceptibility was measured with a kappabridge susceptometer [Jelínek and Pokorný, 1997] at Institut des Sciences de la Terre d'Orléans (ISTO). A statistical analysis of the AMS data was carried out using the ANISOFT package of programs [Jelínek, 1978; Hrouda et al., 1990]. Furthermore, in order to understand the geological significance of these measured magnetic fabrics, the identification of the main carriers that contribute to the magnetic signal was undertaken. The magnetic mineralogy was investigated with the following methods: (1) the mean magnetic susceptibility $\left(K_{m}\right),(2)$ thermomagnetic measurements (K(T) curves), and (3) hysteresis loops. Thermal magnetic experiments were performed at Institut des Sciences de la Terre d'Orléans (ISTO, France) using a kappabridge susceptometer coupled to a CS3 furnace and a pump-assisted cooling system. Samples were heated from room temperature to $700^{\circ} \mathrm{C}$ and subsequently cooled down to $40^{\circ} \mathrm{C}$. Resulting $\mathrm{K}(T)$ curves were treated with Cureval 8 software (AGICO). Magnetic hysteresis loops were obtained with a homemade magnetic inductometer at Institut de Physique du Globe de Paris (Saint-Maur, France).

\subsubsection{Magnetic Mineralogy}

Figure 12a shows the distribution of the mean magnetic susceptibility ( $K_{m}$ expressed in $\left.\mu \mathrm{SI}\right)$ deduced from the laboratory measurements of the 28 sampling sites. $K_{m}$ displays a rather large range of values, from $203 \mu \mathrm{SI}$ to $21,200 \mu \mathrm{SI}$. At first glance, a broad correlation between petrographic facies type and $K_{m}$ variations can be observed, with higher $K_{m}$ values from the granodioritic border facies $(5690 \mu \mathrm{SI}$ to $21,200 \mu \mathrm{SI})$ than those to the inner facies $(230 \mu \mathrm{SI}$ to $8240 \mu \mathrm{SI})$. Interestingly, all measurements within the 

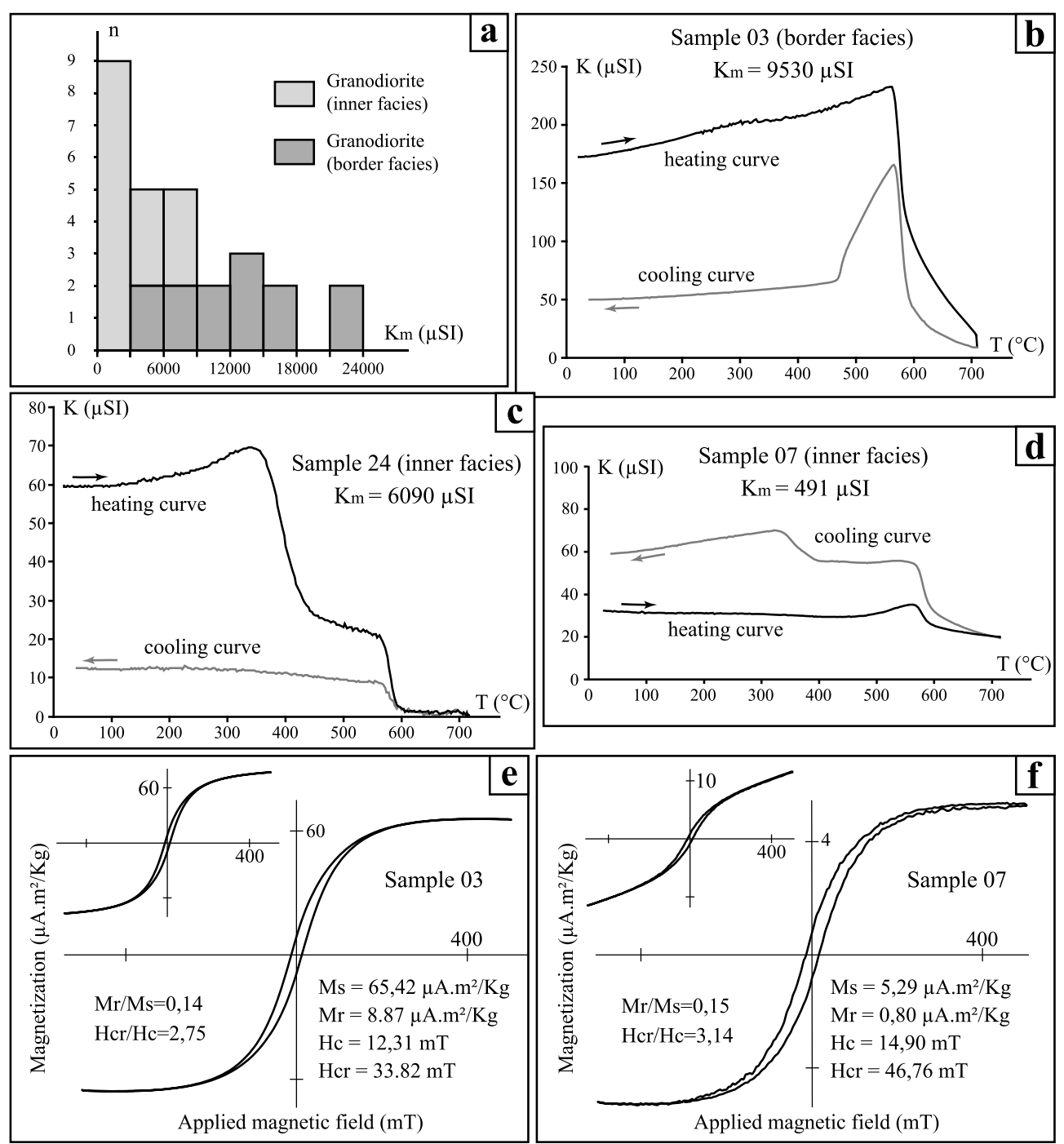

Figure 12. Magnetic mineralogy. (a) Histogram of the mean magnetic susceptibility values $\left(K_{m}\right)$. (b-d) Examples of thermomagnetic curves (see text for explanations). (e and f) Representative hysteresis loops showing the typical shape for the ferromagnetic minerals. Paramagnetic corrections have been applied to the loops, but the uncorrected loops are also shown in the inset. Hysteresis parameter values are also indicated with $M_{\mathrm{rs}}=$ saturation remanence, $M_{s}=$ saturation magnetization, $H_{\mathrm{cr}}=$ remanent coercivity, and $H_{c}=$ coercivity of mineral. Hysteresis ratios $\left(M_{r} / M_{s}\right.$ and $\left.H_{\mathrm{cr}} / H_{c}\right)$ are characteristic of pseudosingle domain magnetite grains.

border facies exhibit $K_{m}$ values larger than $5000 \mu \mathrm{Sl}$, a threshold beyond which the effect of paramagnetic contribution can be considered insignificant in granitic rocks [e.g., Hrouda and Kahan, 1991]. This implies a ferromagnetic behavior with the presence of magnetite-type minerals as main carriers of AMS. In contrast, $K_{m}$ measurements from the inner facies define a more complex distribution: (1) $20 \%$ of sampling sites reveal a $K_{m}$ less than $500 \mu \mathrm{Sl}$, usually attributed to the paramagnetic contribution such as Fe-bearing silicates [e.g., Rochette et al., 1992; Bouchez, 2000]; (2) 20\% with a ferromagnetic contribution $\left(K_{m}>5000 \mu \mathrm{SI}\right)$; and (3) $60 \%$ of these sites fall in the $K_{m}$ range of $500-5000 \mu \mathrm{SI}$, suggesting a combined effect of both ferromagnetic and paramagnetic minerals.

In addition, thermomagnetic measurements widely reflect multimineral contributions. The resulting $\mathrm{K}(T)$ curves can be ranked in three different groups according to the heating curve geometry. From the higher to the lower $K_{m}$ value, one can recognize (1) heating curves with a sharp drop of the magnetic susceptibility from $550^{\circ} \mathrm{C}$ to $580^{\circ} \mathrm{C}$ (Figure $12 \mathrm{~b}$ ), consistent with the Curie point $\left(T_{c}\right)$ of magnetite at $580^{\circ} \mathrm{C}$ [e.g., Dunlop and Özdemir, 1997]. A subsidiary decrease of the magnetic susceptibility from $600^{\circ} \mathrm{C}$ to $700^{\circ} \mathrm{C}$ 


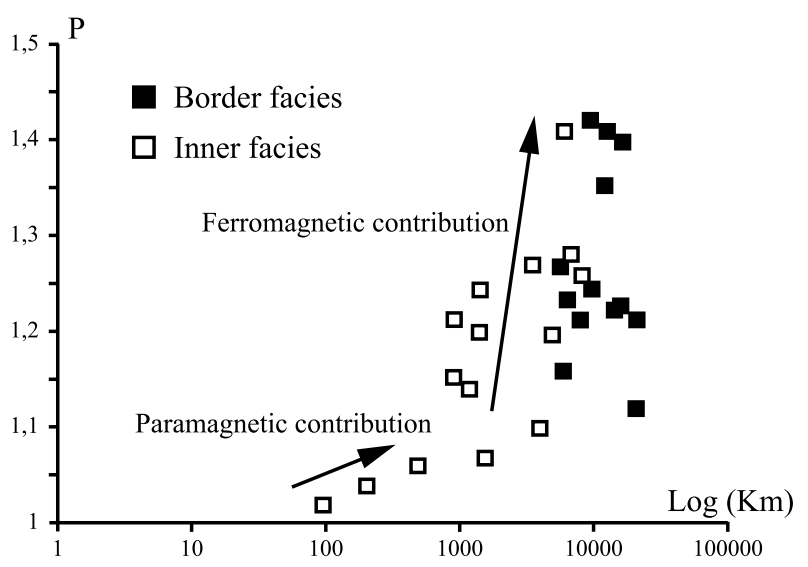

Figure 13. $P\left(K_{m}\right)$ diagram showing a broad correlation between $P$ (degree of anisotropy) and $K_{m}$ values due to the iron content of ferromagnetic minerals and paramagnetic mafic silicates. can also be observed, indicating a minor contribution of maghemite, an oxidized magnetite $\left(T_{C}=590-675^{\circ} \mathrm{C}\right.$ [Dunlop and Özdemir, 1997]). (2) Ferromagnetic curves with an abrupt decrease in magnetic susceptibility from 350 to $420^{\circ} \mathrm{C}$ (Figure 12C) probably due to the Curie point of Ti-poor titanomagnetite (or titanomaghemite) [e.g., Keefer and Shive, 1981], followed by a sudden drop at $580^{\circ} \mathrm{C}\left(T_{\mathrm{c}}\right.$ magnetite), and (3) heating curves with a hyperbolic geometry suggesting that the magnetic signal is controlled by paramagnetic mineral phases [Hrouda, 1994]. In some case, this regular decay is concealed above $400-500^{\circ} \mathrm{C}$ by a

weak peak in magnetic susceptibility (Figure 12d) caused by either a progressive unblocking of single-domain ferromagnetic grains before the Curie point or a neoformation of magnetite from the iron existing in paramagnetic mineral phases [Dunlop and Özdemir, 1997].

Figures $12 \mathrm{e}$ and $12 \mathrm{f}$ exhibit hysteresis loops of two representative samples, one from the border facies (Sample 03; $K_{m}=9530 \mu \mathrm{SI}$ ) and one from the inner facies with low $K_{m}$ value (Sample 07; $K_{m}=491 \mu \mathrm{SI}$ ). A paramagnetic correction was applied to the linear part of original loops (see upper left insets). The induced magnetic moment varies from the order of $10^{-1}$ to $10^{1} \mu \mathrm{Am} / \mathrm{kg}$, which indicates a relatively weak content of magnetic minerals within the granodiorite. Furthermore, the narrow-waisted loops and the low-coercivity values for both specimens indicate that the ferromagnetic contribution is predominantly carried by the magnetite. Ratios of hysteresis parameters $M_{r} / M_{s}$ and $H_{c r} / H_{c}$ also reveal a mean magnetic grain size within the pseudosingle domain (PSD) range [Day et al., 1977; Dunlop, 2002a, 2002b].

To summarize, thermomagnetic measurements and hysteresis loops show that magnetic susceptibility vary according to petrofacies type and the relative contents of ferromagnetic minerals (magnetite, maghemite, and titanomagnetite) and paramagnetic mafic silicates (e.g., biotite and hornblende). In this study, $P$ and $T$ parameters, usually used to describe the degree of AMS and the shape of the AMS ellipsoid, respectively [Nagata, 1961; Jelinek, 1981], cannot constrain strain pattern because of mixed paramagnetic and ferromagnetic mineralogy. As shown in Figure 13, a close correlation between $P$ and $K_{m}$ can be observed, with lower degrees of anisotropy within paramagnetic samples than those to the ferromagnetic samples.

\subsubsection{Map-Scale Pattern of Magnetic Fabric and Comparison With Mesoscopic Fabric}

Orientations of the magnetic foliation (defined as the plane normal to $K_{3}$ ) and magnetic lineations (parallel to $K_{1}$ ) are illustrated as locality mean values on the maps (Figures $7 \mathrm{a}$ and $7 \mathrm{~b}$ ). In areas where both magnetic and mesoscopic fabrics have been measured, orientations of magnetic foliation and magnetic lineation are broadly consistent with structural field observations. We consequently assume that the following map-scale pattern can be presented and subsequently discussed.

At map scale, magnetic foliations together with mesoscopic foliations display an elliptic configuration with NE-SW directed long axis (Figure 7a). Note that these foliations throughout the pluton are fairly parallel to the petrographic contacts. Importantly, along NE-SW cross section, the magnetic foliation dips moderately to the NE close to the northeastern margin, becomes steeper in the core, and dips gently to the SW in the southwestern margin of the pluton.

At map scale, magnetic lineations are homogeneously oriented with mesoscopic lineations and concordant with the southwest directed stretching lineation measured along the Vaghia shear zone and the Aghios Sostis detachment (Figure 7b). Toward the pluton core, lineations trend to the south with subvertical plunges that become gentler at the southern and southwestern margins of the pluton where the trend is constantly NE-SW. In contrast, lineations at the northeastern margin define a complex pattern. Two sets of lineation trends have been recognized: (1) an abundant NE-SW family representing the continuity of the lineations 
found in the whole granodiorite; (2) locally, an E-W family is observed near the petrographic contact between the inner and border facies.

\section{Discussion}

6.1. Evidence for a Continuum of Deformation in Serifos Pluton From Magmatic to Ductile/Brittle Solid-State Conditions

Our new field investigations, together with microstructural and AMS data, allow us to recognize a continuum of deformation from magmatic to brittle conditions within the Serifos pluton. This succession of deformation events, entirely kinematically compatible with the top-to-the-SW shearing in host rocks, undoubtedly shows the contemporaneity between the development of the WCDS and pluton emplacement. Moreover, following the distribution of both microstructures and mesoscopic fabrics, it should be noted that the Serifos pluton has undergone a localized southwestward gradient of shearing, leaving preserved magmatic fabrics in the northern and central parts.

In the northern and central parts of the Serifos pluton, both the coarse-grained and fine-grained facies display a weak or indiscernible mesoscopic fabrics, and they show magmatic textures without any significant solid-state overprint. Consequently, we consider that the obtained magnetic fabric reflects probably a magmatic fabric developed close to magma solidus [Vernon, 2000]. Both mesoscopic and magnetic foliations display a well-defined elliptic pattern carrying a NE-SW oriented long axis. These foliations, fairly parallel to the wall-rock contact, may represent relics of emplacement-related fabric. More specifically, the magmatic lineations measured in the central part are constantly oriented to the southwest and concordant to stretching lineations observed in the host metamorphic rocks along the WCDS. This observation leads us to interpret this fabric orientation as recording a synmagmatic flow, tectonically driven by the NE-SW regional extension. Conversely, E-W to NW-SE trending magnetic lineations have been locally detected by AMS in the northeastern part of the pluton. The interpretation of such magnetic lineations is not straightforward. In our case, this could be due to either physical or geological reasons: the former being (1) the predominance of pseudosingle domain (PSD) magnetite grains that control AMS signal could produce an abnormal fabric [Rochette et al., 1999]; (2) anisotropic distribution of ferromagnetic particles [Hargraves et al., 1991]; (3) lack of mineral preferred orientation at some sample sites, the latter being (4) emplacement-related magma flow along E-W to NW-SE oriented tensional zones whose direction of opening could be consistent with the NE-SW directed regional extension.

Overprinting of a constrictional deformation on the previous northeastern synmagmatic fabric can be observed along the southern rim where the border facies displays a strongly prolate fabric, NE-SW subhorizontal lineations, and locally LT solid-state microstructures. We further contend that the measured constrictional fabric in this area could reflect a southwestward synmagmatic flow which could be incompletely overprinted by regional strain and tectonically driven by vertical shortening associated to the NE-SW regional extension. As revealed by both field and microstructural observations, the prolate fabric was subsequently overprinted by a top-to-the-SW ductile shearing according to an upward and southwestward gradient of shearing. The granodioritic fabric progressively evolves from weakly oblate to strongly oblate, resulting into mylonites close to the SW directed Koutalas-Vaghia shear zone.

Along its eastern margin (Aghios Sostis Peninsula), the roof was affected by a low-angle normal fault consistently compatible with a southwest directed extension. Structural observations show a diffuse strain gradient in the footwall from undeformed granodiorite to LT ultramylonites below the detachment. Tschegg and Grasemann [2009] had especially described dislocation climb in K-feldspar as well as isochemical nucleation and growth of new grains of K-feldspar in ultramylonites, suggesting deformation temperatures above $450-500^{\circ} \mathrm{C}$ at relevant strain rates [Passchier and Trouw, 2005, and references therein]. According to these results, since the pluton intruded the Cycladic Blueschists piercing the Meghàlo Livadhi detachment whose shear deformation is well constrained to $300^{\circ} \mathrm{C}$ [Grasemann and Tschegg, 2012; Dabrowski and Grasemann, 2014], the Aghios Sostis shear zone should have nucleated during the cooling of the pluton and continued to develop afterward.

Finally, ductile/brittle to brittle, WNW-ESE striking, conjugate high-angle normal faults crosscut the whole Serifos Island, including the granodiorite and the metamorphic host rocks. These faults suggest ongoing NE-SW extension after ductile exhumation of the dome. 


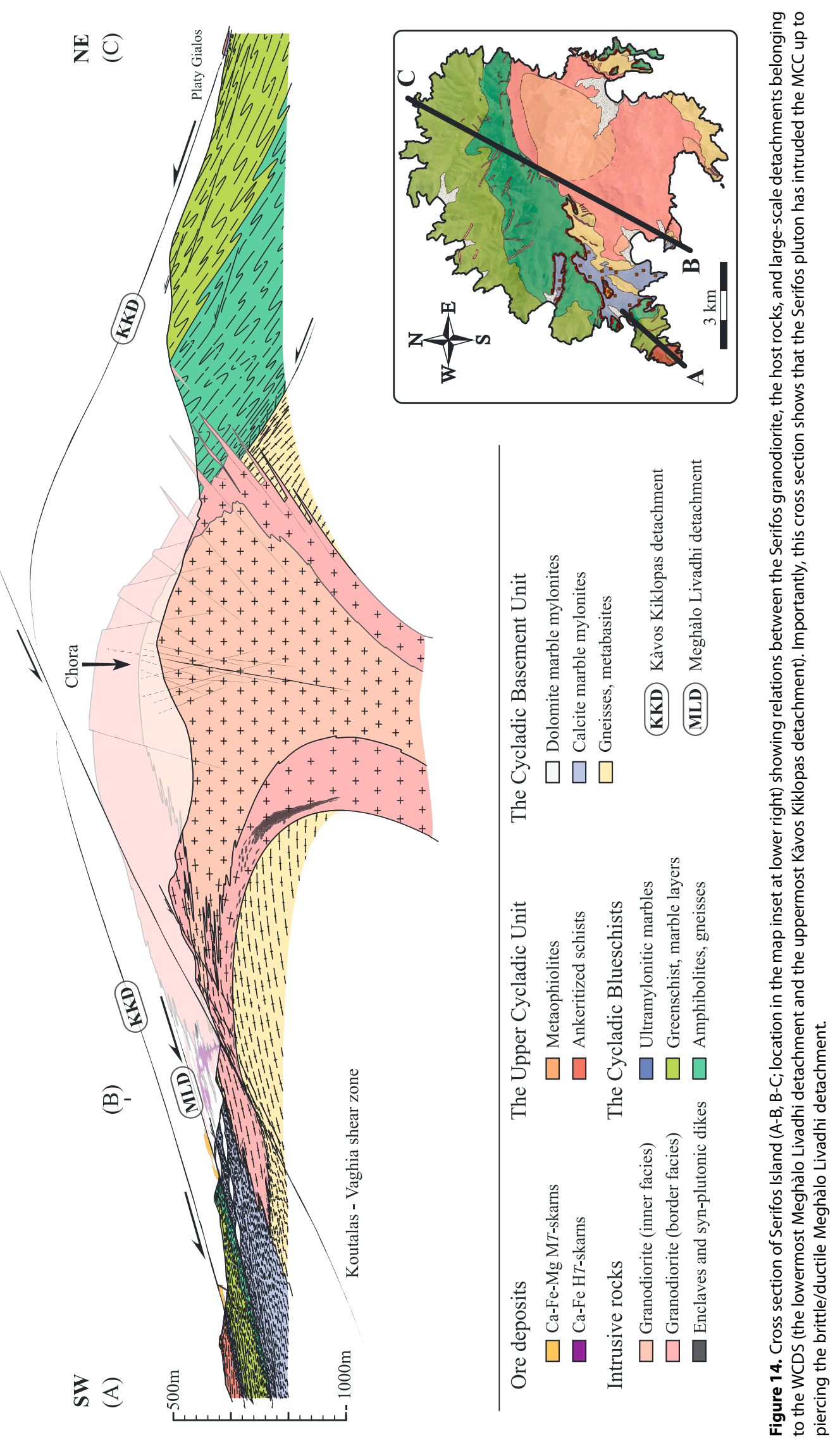




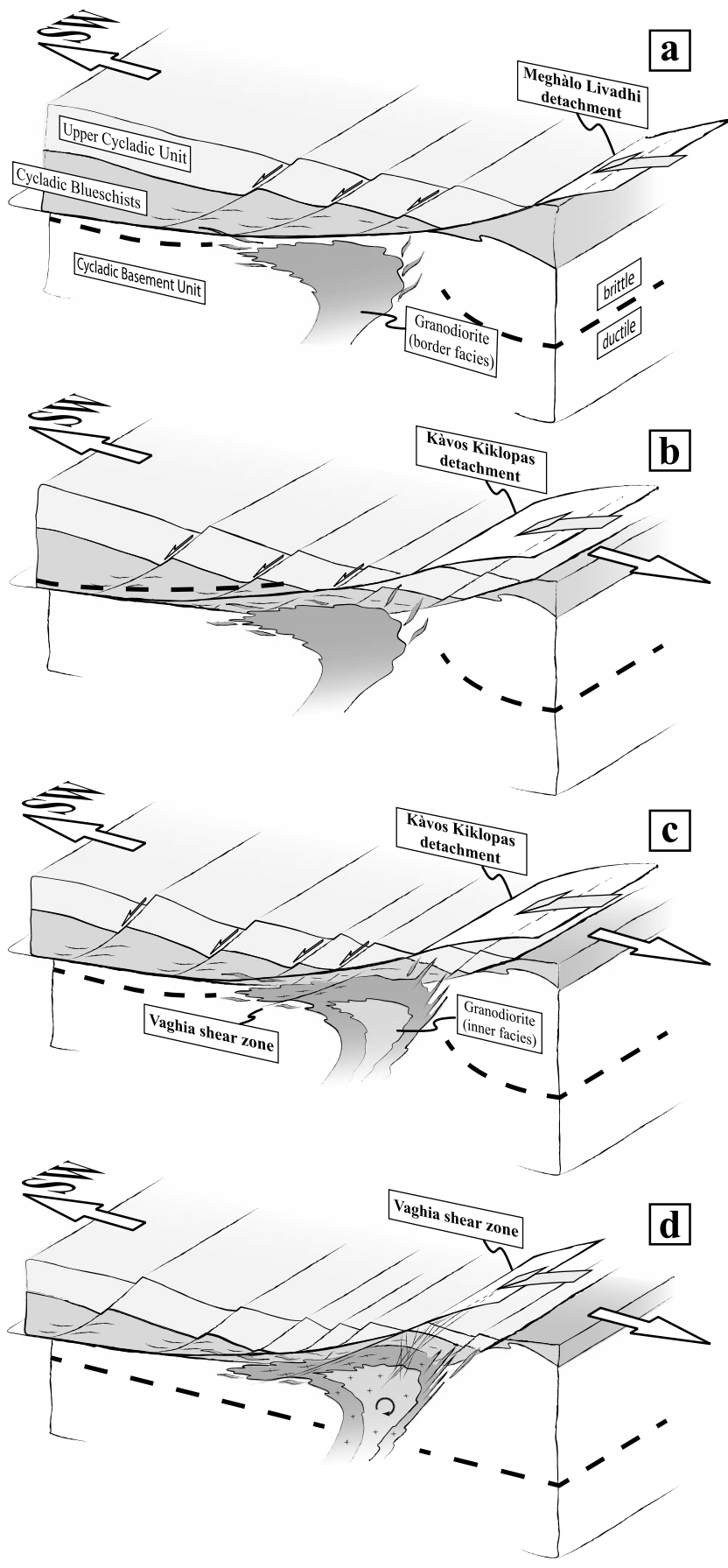

Figure 15. The 3-D views showing the tectonic scenario for the Serifos pluton emplacement and its cooling in interaction with the WCDS (West Cycladic Detachment System) during the Aegean crustal extension (see explanation in the text for each stage).

\subsection{Building of Detailed Cross Section of Serifos Island}

On the basis of our own field study, we propose a detailed NE-SW cross section of Serifos Island, in which geometrical relationships between the pluton, host rocks, and major structures are highlighted (Figure 14).

The metamorphic dome and the granodiorite were exhumed below two branches of a crustal-scale low-angle normal fault system. The detachment system is arched with northeast dipping planes at Platy Gialos to the north and southwest dipping planes at Meghàlo Livadhi and Kàvos Kiklopas. It provides evidence that the granodioritic intrusion was coeval with an overall updoming of the surrounding host rocks before it perforated the lower Meghàlo Livadhi detachment. A continuum from ductile to brittle conditions and a stable top-to-the-SW shearing shows the progressive exhumation of the dome below the WCDS. The Kàvos Kiklopas detachment was formed above the Meghàlo Livadhi detachment, and it was more localized. Extensional shearing was also associated with exoskarn and endoskarn mineralizations showing hydrothermal circulations of fluids during intrusion and cooling of the pluton.

The NE-SW cross section thereby shows a complete section of the pluton with superficial parts of the intrusion to the north and deeper ones to the south. The northern part shows a sharp intrusive contact with preserved magmatic fabric, while the pluton was progressively affected by a top-to-the-SW ductile shearing to the southwest rim, gradually transformed into mylonites or even ultramylonites at its eastern margin. The marginal coarse-grained facies of the granodiorite was thus dissected by a series of ductile extensional shear zones, kinematically and temporally consistent with the development of the WCDS. These shear zones have been arched upward during later doming, but they also cut the intrusion downsection toward the southwest. The deepest parts of the intrusion are also rich in swarms of enclaves, dike-like monogenic swarms, and partially disaggregated synplutonic dikes. They have been formed by magmatic mingling processes involving mafic magma intrusion within partially crystallized host granodioritic magma. Field observations further show that their morphologies and their mesoscopic fabrics are compatible with the fabric of both the host granodiorite and the metamorphic host rocks. The asymmetric 
disaggregation of NW-SE striking subvertical synplutonic dikes could be explained by the pulling force to the southwest of these synplutonic dikes during their injection within a general top-to-the SW noncoaxial flow.

In areas where magmatic fabric is preserved without any ductile shearing overprint, especially west of Chora and Livadhi villages, the coarse-grained facies shows steeply dipping foliations and N-S to NE-SW subvertical lineations. The SL fabric could then represent in this case a subvertical magmatic flow coming out of the feeding zone. In the absence of direct information on the deep structure that gravimetry or drilling could provide, we tentatively suggest that the Serifos pluton is an asymmetrical intrusion with a root zone offset toward the north (Chora village). The deepest parts of the intrusion with magmatic inclusions have been dragged southwestward along southwest dipping shear zones, while the magma was still unconsolidated and ultimately sheared below the WCDS. A similar geometry was inferred for other plutons emplaced into zones affected by noncoaxial shearing [Bouillin et al., 1993; Acocella and Rossetti, 2002; Kratinová et al., 2007; Denèle et al., 2011; Lehmann et al., 2013; Laurent et al., 2015] and also modeled by Schulmann and Ježek [2012].

\subsection{Tectonic Scenario for the Serifos Pluton Emplacement and Cooling}

Intrusion, cooling, and internal deformation of the Serifos granodiorite were synchronous with southwestward shearing along crustal-scale low-angle normal faults that evolved during the Miocene. Integrating existing data and our new observations, we propose the following tectonic scenario of Serifos Island, which can be isolated into four main stages from MCC development to granodiorite unroofing during crustal extension (Figure 15).

1. The first stage is related to greenschist retrogression that affected the two lower Cycladic units outcropping on Serifos Island. In the Cyclades, LP-HT metamorphism has been interpreted as the result of OligoceneMiocene crustal-scale extension controlled by the southward fast retreat of the African slab from approximately 35-30 Ma [Jolivet and Faccenna, 2000; Jolivet and Brun, 2010; Ring et al., 2010]. During this episode, the change of stress regime is accompanied by a strong heating that led to partial melting of the lower extending crust [Jolivet and Brun, 2010; Jolivet et al., 2010, 2013]; migmatite domes thus developed in the central parts of the Aegean domain [i.e., Vanderhaeghe, 2004]. The upper crust recorded bivergent crustal-scale boudinage leading to development of the Cycladic MCCs and associated northern and western detachment systems [Lister et al., 1984; Gautier and Brun, 1994a; Jolivet et al., 2010; Grasemann et al., 2012].

On Serifos Island, extension and exhumation were accommodated by the upper Kàvos Kiklopas branch and the lower Meghàlo Livadhi branch of the WCDS [Grasemann and Petrakakis, 2007; Grasemann et al., 2012] with similar NE-SW oriented stretching lineation and southwest directed shear sense. Observations of preserved earlier ENE-WSW oriented stretching lineation in a large part of the island testify for a strongly localized deformation along these crustal-scale detachments, more localized than along the NCDS or farther west along the WCDS. The earlier ENE-WSW directed stretching lineation is indeed strongly overprinted by southwest directed shearing on Kea and well preserved on Kythnos where the WCDS crops out [Iglseder et al., 2011; Grasemann et al., 2012]. On Serifos, thermochronological data suggest that the overall cooling of the Cycladic Blueschists and the Cycladic Basement Unit below approximately $450 \pm 50^{\circ} \mathrm{C}$ [Villa, 1998] occured at approximately $15 \mathrm{Ma}$ (Rb/Sr muscovite ages [Iglseder et al., 2009] and ${ }^{40} \mathrm{Ar} /{ }^{39} \mathrm{Ar}$ ages muscovite [Grasemann et al., 2012]). However, the exact onset of ductile shearing along each detachment is unclear. On Kea and Kythnos Islands, cooling ages suggest that ductile shearing along the WCDS was active between 21 and 13 Ma and between 26 and 20 Ma, respectively [Schliestedt et al., 1994; Iglseder et al., 2011; Grasemann et al., 2012].

Taking into account structural observations, we assume that the MCC initiation and associated top-to-theSW shearing are due to a single detachment that migrated upward with time. This tectonic evolution can be interpreted as the result of the interrelations between regional tectonics and the more local plutonic intrusion. Southwest directed extensional shearing was first localized along the lowermost Meghàlo Livadhi detachment, leading to the Cycladic Basement Unit exhumation (Figure 15a). Furthermore, the observation that a continuum of deformation from ductile to brittle conditions was recorded along the Meghàlo Livadhi detachment shows that the whole system had already crossed the brittle-ductile transition zone before it was perforated by the intrusion.

2. The second stage is marked by the Serifos pluton emplacement and associated dikes at shallow crustal level above the brittle-ductile transition zone (approximately 8-12 km depth [Stouraiti and Mitropoulos, 1999; St. Seymour et al., 2009]). Between 11.6 Ma and 9.5 Ma (U/Pb zircon ages [lglseder et al., 2009]), the Serifos pluton 
has intruded the MCC up to piercing the brittle/ductile Meghàlo Livadhi detachment (Figure 15b). The plutonic body and associated dikes clearly crosscut both the Meghàlo Livadhi detachment and the regional preexisting metamorphic fabric. Most of the dikes are parallel with/or follow the NW-SE striking, brittle high-angle normal faults, attesting for pluton emplacement at upper crustal depth. Contemporaneously, the granodioritic intrusion radically altered the local temperature, reheating host rocks and inducing some ductile deformation. Southwest directed extensional shearing was thereby transferred upward in the crust along the more localized Kàvos Kiklopas detachment, where high-strain was mainly accommodated by few meter thick ultramylonitic marbles. The upward migration of the detachment due to intrusions is similarly recorded along the NCDS in the islands of Tinos and Mykonos [Jolivet and Patriat, 1999; Jolivet et al., 2010].

3. Subsequently, pluton emplacement was followed by a rather fast cooling [Altherr et al., 1982; Iglseder et al., 2009]. During the magmatic crystallization, both the coarse-grained (i.e., border facies) and fine-grained (i.e., inner facies) granitoids were affected in a short time by a synmagmatic extensional deformation below the Kàvos Kiklopas detachment (Figure 15c). The large-scale structure of the pluton, especially its overall asymmetry, was entirely controlled by the top-to-the-southwest shearing associated with the WCDS, while noncoaxial deformation localized, leading to the nucleation of narrow shear zones during pluton cooling.

4. After the complete crystallization of the pluton, the top-to-the-SW extensional deformation continued to affect both the pluton and the metamorphic dome. Ductile shearing was increasingly localized with time at the southwestern and eastern margins where the Vaghia and the Aghios Sostis shear zones developed, leaving preserved magmatic fabrics at northern and central parts of the pluton. During the final exhumation stage, series of ductile extensional shear zones that dissected both the pluton and the metamorphic dome evolved through time into brittle detachments (Figure 15d). Afterward, NW-SE striking, conjugate high-angle normal faults crosscut the whole Serifos Island. These structures suggest ongoing NE-SW extension after ductile/brittle exhumation of the Serifos MCC. In this scenario, we assume that the end of exhumation to the surface has been achieved by this set of steep normal faults and/or other unroofing mechanism such as erosion.

\section{Conclusion}

Serifos Island forms a well-suited example to study the interrelations between plutonic activity and localizing events in the crust during MCC formation. Serifos Island, located in the western Cyclades (Greece), is described as a MCC intruded by an I-type granodiorite at shallow crustal levels. This Miocene pluton had intruded during the thinning of the Aegean Sea, and it was spatially connected to the activity of the WCDS. Based on a structural fieldwork, together with microstructural and AMS data, we have recognized a continuum of deformation from magmatic to brittle conditions in the Serifos pluton during its cooling and subsequent unroofing, consistent with the top-to-the-southwest shearing recorded within host rocks. Serifos pluton thereby shows a strong asymmetric architecture with preserved magmatic fabrics northeastward and a southwestern margin sheared toward the south along the WCDS.

The existing data and our new observations made on Serifos Island thus lead to propose a tectonic scenario for the Miocene pluton emplacement in extending crust, along the WCDS: (1) a first stage corresponding to the MCC initiation and associated ductile shearing along the lowermost Meghàlo Livadhi detachment; (2) a second stage related to the Serifos pluton emplacement above the brittle-ductile transition, piercing through the ductile/brittle Meghàlo Livadhi detachment. Intrusion inactivated the deeper branch, and the southwest oriented extensional deformation migrated upward in the crust along the more localized Kàvos Kiklopas detachment. (3) After pluton emplacement, the Serifos pluton recorded in short time span strain

Acknowledgments

Data sets are available upon request from the first author. This work was funded by the European Research Council (ERC) under the 7th Framework Programme of the European Union (ERC Advanced Grant, grant agreement 290864, RHEOLITH) with a contribution from the Laboratoire d'Excellence (LABEX) VOLTAIRE (Convention no. ANR10-LABEX-100-01) of the University of Orléans. The authors wish to express their thanks to Jiři Žák and anonymous reviewers for their useful comments. localization resulting in shear zones nucleation during its cooling, and (4) their subsequent development after the complete crystallization of the pluton. Continuum of deformation finally evolved to a brittle regime during the later exhumation stage.

\section{References}

Acocella, V., and F. Rossetti (2002), The role of extensional tectonics at different crustal levels on granite ascent and emplacement: An example from Tuscany (Italy), Tectonophysics, 354(1-2), 71-83, doi:10.1016/S0040-1951(02)00290-1.

Aktug, B., et al. (2009), Deformation of western Turkey from a combination of permanent and campaign GPS data: Limits to block-like behavior, J. Geophys. Res., 114, B10404, doi:10.1029/2008JB006000.

Altherr, R., and W. Siebel (2002), l-type plutonism in a continental back-arc setting: Miocene granitoids and monzonites from the central Aegean Sea, Greece, Contrib. Mineral. Petrol., 143(4), 397-415, doi:10.1007/s00410-002-0352-y. 
Altherr, R., M. Schliestedt, M. Okrusch, E. Seidel, H. Kreuzer, W. Harre, H. Lenz, I. Wendt, and G. A. Wagner (1979), Geochronology of high-pressure rocks on Sifnos (Cyclades, Greece), Contrib. Mineral. Petrol., 70(3), 245-255, doi:10.1007/BF00375354.

Altherr, R., H. Kreuzer, I. Wendt, H. Lenz, G. A. Wagner, J. Keller, W. Harre, and A. Höhndorf (1982), A late Oligocene/early Miocene high temperature belt in the Attic-Cycladic crystalline complex (SE Pelagonian, Greece), Geol. Jahrb., E23, 97-164.

Altherr, R., F. Henjes-Kunst, A. Matthews, H. Friedrichsen, and B. T. Hansen (1988), O-Sr isotopic variations in Miocene granitoids from the Aegean: Evidence for an origin by combined assimilation and fractional crystallization, Contrib. Mineral. Petrol., 100(4), 528-541, doi:10.1007/BF00371381.

Andriessen, P. A. M., G. Banga, and E. H. Hebeda (1987), Isotopic age study of pre-Alpine rocks in the basal units on Naxos, Sikinos and los, Greek Cyclades, Geol. Mijnbouw, 66, 3-14.

Archanjo, C. J., P. Launeau, and J. L. Bouchez (1994), Magnetic fabric vs. magnetite and biotite shape fabrics of the magnetite-bearing granite pluton of Gameleiras (Northeast Brazil), Phys. Earth Planet. Inter., 89(1-2), 63-75, doi:10.1016/0031-9201(94)02997-P.

Armijo, R., H. Lyon-Caen, and D. Papanastassiou (1992), East-west extension and Holocene normal-fault scarps in the Hellenic arc, Geology, 20(6), 491, doi:10.1130/0091-7613(1992)020<0491:EWEAHN>2.3.CO;2.

Armijo, R., B. Meyer, G. C. P. King, A. Rigo, and D. Papanastassiou (1996), Quaternary evolution of the Corinth Rift and its implications for the Late Cenozoic evolution of the Aegean, Geophys. J. Int., 126(1), 11-53, doi:10.1111/j.1365-246X.1996.tb05264.x.

Armijo, R., B. Meyer, A. Hubert, and A. Barka (1999), Westward propagation of the North Anatolian fault into the northern Aegean: Timing and kinematics, Geology, 27(3), 267, doi:10.1130/0091-7613(1999)027<0267:WPOTNA>2.3.CO;2.

Augier, R., L. Jolivet, L. Gadenne, A. Lahfid, and O. Driussi (2014), Exhumation kinematics of the Cycladic Blueschists unit and back-arc extension, insight from the Southern Cyclades (Sikinos and Folegandros Islands, Greece), Tectonics, 34, 152-185, doi:10.1002/ 2014 TC003664.

Baldwin, S. L., G. S. Lister, E. J. Hill, D. A. Foster, and I. McDougall (1993), Thermochronologic constraints on the tectonic evolution of active metamorphic core complexes, D'entrecasteaux Islands, Papua New Guinea, Tectonics, 12(3), 611-628, doi:10.1029/93TC00235.

Barbarin, B. (2005), Mafic magmatic enclaves and mafic rocks associated with some granitoids of the central Sierra Nevada batholith, California: Nature, origin, and relations with the hosts, Lithos, 80(1-4), 155-177, doi:10.1016/j.lithos.2004.05.010.

Benn, K., S. R. Paterson, S. P. Lund, G. S. Pignotta, and S. Kruse (2001), Magmatic fabrics in batholiths as markers of regional strains and plate kinematics: Example of the Cretaceous Mt. Stuart batholith, Phys. Chem. Earth Part A., 26(4-5), 343-354, doi:10.1016/S1464-1895(01) 00064-3.

Bolhar, R., U. Ring, and C. M. Allen (2010), An integrated zircon geochronological and geochemical investigation into the Miocene plutonic evolution of the Cyclades, Aegean Sea, Greece: Part 1: Geochronology, Contrib. Mineral. Petrol., 160(5), 719-742, doi:10.1007/s00410-010-0504-4 Bonneau, M. (1984), Correlation of the Hellenide nappes in the south-east Aegean and their tectonic reconstruction, Geol. Soc. London Spec. Publ., 17(1), 517-527, doi:10.1144/GSL.SP.1984.017.01.38.

Borradaile, G. J., and B. Henry (1997), Tectonic applications of magnetic susceptibility and its anisotropy, Earth Sci. Rev., 42(1-2), 49-93, doi:10.1016/S0012-8252(96)00044-X.

Borradaile, G. J., and M. Jackson (2010), Structural geology, petrofabrics and magnetic fabrics (AMS, AARM, AIRM), J. Struct. Geol., 32(10), 1519-1551, doi:10.1016/j.jsg.2009.09.006.

Bouchez, J. L., G. Gleizes, T. Djouadi, and P. Rochette (1990), Microstructure and magnetic susceptibility applied to emplacement kinematics of granites: The example of the foix pluton (French pyrenees), Tectonophysics, 184(2), 157-171, doi:10.1016/0040-1951(90)90051-9.

Bouchez, J.-L. (2000), Anisotropie de susceptibilité magnétique et fabrique des granites, C. R. Acad. Sci., Ser. IIA: Earth Planet. Sci., 330(1), 1-14, doi:10.1016/S1251-8050(00)00120-8.

Bouillin, J.-P., J.-L. Bouchez, P. Lespinasse, and A. Pe^cher (1993), Granite emplacement in an extensional setting: An AMS study of the magmatic structures of Monte Capanne (Elba, Italy), Earth Planet. Sci. Lett., 118(1-4), 263-279, doi:10.1016/0012-821X(93)90172-6.

Bozkurt, E., and H. Sözbilir (2004), Tectonic evolution of the Gediz Graben: Field evidence for an episodic, two-stage extension in western Turkey, Geol. Mag., 141(1), 63-79, doi:10.1017/S0016756803008379.

Brichau, S., U. Ring, A. Carter, P. Monié, R. Bolhar, D. Stockli, and M. Brunel (2007), Extensional faulting on Tinos Island, Aegean Sea, Greece: How many detachments?, Tectonics, 26, TC4009, doi:10.1029/2006TC001969.

Brichau, S., U. Ring, A. Carter, R. Bolhar, P. Monie, D. Stockli, and M. Brunel (2008), Timing, slip rate, displacement and cooling history of the Mykonos detachment footwall, Cyclades, Greece, and implications for the opening of the Aegean Sea basin, J. Geol. Soc., 165(1), 263-277, doi:10.1144/0016-76492006-145.

Brichau, S., S. Thomson, and U. Ring (2010), Thermochronometric constraints on the tectonic evolution of the Serifos detachment, Aegean Sea, Greece, Int. J. Earth Sci., 99(2), 379-393, doi:10.1007/s00531-008-0386-0.

Bröcker, M., and M. Enders (1999), U-Pb zircon geochronology of unusual eclogite-facies rocks from Syros and Tinos (Cyclades, Greece), Geol. Mag., 136(2), 111-118, doi:10.1017/S0016756899002320.

Bröcker, M., H. Kreuzer, A. Matthews, and M. Okrusch (1993), Ar-40 Ar-39 and oxygen isotope studies of polymetamorphism from Tinos Island, Cycladic blueschist belt, Greece, J. Metamorph. Geol., 11(2), 223-240, doi:10.1111/j.1525-1314.1993.tb00144.x.

Brown, M. (1994), The generation, segregation, ascent and emplacement of granite magma: The migmatite-to-crustally-derived granite connection in thickened orogens, Earth Sci. Rev., 36(1-2), 83-130, doi:10.1016/0012-8252(94)90009-4.

Brun, J.-P., and D. Sokoutis (2010), 45 m.y. of Aegean crust and mantle flow driven by trench retreat, Geology, 38(9), 815-818, doi:10.1130/ G30950.1.

Charles, N., C. Gumiaux, R. Augier, Y. Chen, R. Zhu, and W. Lin (2011), Metamorphic core complexes vs. synkinematic plutons in continental extension setting: Insights from key structures (Shandong Province, eastern China), J. Asian Earth Sci., 40(1), 261-278, doi:10.1016/j.jseaes.2010.07.006.

Crittenden, M. D., P. J. Coney, and G. H. Davis (1980), Cordilleran metamorphic core complexes, Geol. Soc. Am., $153,490$.

D'Lemos, R. S., M. Brown, and R. A. Strachan (1992), Granite magma generation, ascent and emplacement within a transpressional orogen, J. Geol. Soc., 149(4), 487-490, doi:10.1144/gsjgs.149.4.0487.

Dabrowski, M., and B. Grasemann (2014), Domino boudinage under layer-parallel simple shear, J. Struct. Geol., 68, 58-65, doi:10.1016/ j.jsg.2014.09.006.

Daniel, J.-M., and L. Jolivet (1995), Detachment faults and pluton emplacement; Elba Island (Tyrrhenian Sea), Bull. Soc. Geol. Fr., 166(4), $341-354$.

Davidson, C., S. M. Schmid, and L. S. Hollister (1994), Role of melt during deformation in the deep crust, Terra Nova, 6(2), 133-142, doi:10.1111/j.1365-3121.1994.tb00646.x.

Davis, G. A., T. K. Fowler, K. M. Bishop, T. C. Brudos, S. J. Friedmann, D. W. Burbank, M. A. Parke, and B. C. Burchfiel (1993), Pluton pinning of an active Miocene detachment fault system, eastern Mojave Desert, California, Geology, 21(7), 627, doi:10.1130/0091-7613(1993)021<0627: PPOAAM $>2.3 . C O ; 2$. 
Day, R., M. Fuller, and V. A. Schmidt (1977), Hysteresis properties of titanomagnetites: Grain-size and compositional dependence, Phys. Earth Planet. Inter., 13(4), 260-267, doi:10.1016/0031-9201(77)90108-X.

Denèle, Y., E. Lecomte, L. Jolivet, O. Lacombe, L. Labrousse, B. Huet, and L. Le Pourhiet (2011), Granite intrusion in a metamorphic core complex: The example of the Mykonos laccolith (Cyclades, Greece), Tectonophysics, 501(1-4), 52-70, doi:10.1016/j.tecto.2011.01.013.

Dunlop, D. J. (2002a), Theory and application of the Day plot (Mrs/Ms versus Hcr/Hc) 1. Theoretical curves and tests using titanomagnetite data, J. Geophys. Res., 107, 2056, doi:10.1029/2001JB000486.

Dunlop, D. J. (2002b), Theory and application of the Day plot (Mrs/Ms versus Hcr/Hc) 2. Application to data for rocks, sediments, and soils, J. Geophys. Res., 107(B3), 2057, doi:10.1029/2001JB000487.

Dunlop, D. J., and O. Özdemir (1997), Rock Magnetism: Fundamentals and Frontiers, Cambridge Univ. Press, Cambridge, New York.

Eyidoğan, H., and J. Jackson (1985), A seismological study of normal faulting in the Demirci, Alaşehir and Gediz earthquakes of 1969-70 in western Turkey: Implications for the nature and geometry of deformation in the continental crust, Geophys. J. Int., 81(3), 569-607, doi:10.1111/j.1365-246X.1985.tb06423.x.

Faure, M., M. Bonneau, and J. Pons (1991), Ductile deformation and syntectonic granite emplacement during the late Miocene extension of the Aegea (Greece), Bull. Soc. Geol. Fr., 162, 3-11.

Foster, D. A., C. Schafer, C. M. Fanning, and D. W. Hyndman (2001), Relationships between crustal partial melting, plutonism, orogeny, and exhumation: Idaho Bitterroot batholith, Tectonophysics, 342(3-4), 313-350, doi:10.1016/S0040-1951(01)00169-X.

Gautier, P., and J.-P. Brun (1994a), Crustal-scale geometry and kinematics of late-orogenic extension in the central Aegean (Cyclades and Ewia Island), Tectonophysics, 238(1-4), 399-424, doi:10.1016/0040-1951(94)90066-3.

Gautier, P., and J.-P. Brun (1994b), Ductile crust exhumation and extensional detachments in the central Aegean (Cyclades and Evvia islands), Geodinamica Acta, 7(2), 57-85.

Gautier, P., J.-P. Brun, R. Moriceau, D. Sokoutis, J. Martinod, and L. Jolivet (1999), Timing, kinematics and cause of Aegean extension: A scenario based on a comparison with simple analogue experiments, Tectonophysics, 315(1-4), 31-72, doi:10.1016/S0040-1951(99)00281-4.

Goldsworthy, M., J. Jackson, and J. Haines (2002), The continuity of active fault systems in Greece, Geophys. J. Int., 148(3), 596-618, doi:10.1046/j.1365-246X.2002.01609.x.

Goscombe, B. D., C. W. Passchier, and M. Hand (2004), Boudinage classification: End-member boudin types and modified boudin structures, J. Struct. Geol., 26(4), 739-763, doi:10.1016/j.jsg.2003.08.015.

Grasemann, B., and K. Petrakakis (2007), Evolution of the Serifos metamorphic core complex, J. Virtual Explor., 27, 1-18.

Grasemann, B., and C. Tschegg (2012), Localization of deformation triggered by chemo-mechanical feedback processes, Geol. Soc. Am. Bull., 124(5-6), 737-745, doi:10.1130/B30504.1.

Grasemann, B., D. A. Schneider, D. F. Stockli, and C. Iglseder (2012), Miocene bivergent crustal extension in the Aegean: Evidence from the western Cyclades (Greece), Lithosphere, 4(1), 23-39, doi:10.1130/L164.1.

Groppo, C., M. Forster, G. Lister, and R. Compagnoni (2009), Glaucophane schists and associated rocks from Sifnos (Cyclades, Greece): New constraints on the P-T evolution from oxidized systems, Lithos, 109(3-4), 254-273, doi:10.1016/j.lithos.2008.10.005.

Hargraves, R. B., D. Johnson, and C. Y. Chan (1991), Distribution anisotropy: The cause of AMS in igneous rocks?, Geophys. Res. Lett., 18(12), 2193-2196, doi:10.1029/91GL01777.

Hatzfeld, D., V. Karakostas, M. Ziazia, I. Kassaras, E. Papadimitriou, K. Makropoulos, N. Voulgaris, and C. Papaioannou (2000), Microseismicity and faulting geometry in the Gulf of Corinth (Greece), Geophys. J. Int., 141(2), 438-456, doi:10.1046/j.1365-246x.2000.00092.x.

Hejl, E., H. Riedl, and H. Weingartner (2002), Post-plutonic unroofing and morphogenesis of the Attic-Cycladic complex (Aegea, Greece), Tectonophysics, 349(1-4), 37-56, doi:10.1016/S0040-1951(02)00045-8.

Henjes-Kunst, F., and H. Kreuzer (1982), Isotopic dating of pre-Alpidic rocks from the island of los (Cyclades, Greece), Contrib, Mineral. Petrol., 80(3), 245-253, doi:10.1007/BF00371354.

Hrouda, F. (1994), A technique for the measurement of thermal changes of magnetic susceptibility of weakly magnetic rocks by the CS-2 apparatus and KLY-2 Kappabridge, Geophys. J. Int., 118(3), 604-612, doi:10.1111/j.1365-246X.1994.tb03987.x.

Hrouda, F., and š. Kahan (1991), The magnetic fabric relationship between sedimentary and basement nappes in the High Tatra Mountains, N. Slovakia, J. Struct. Geol., 13(4), 431-442, doi:10.1016/0191-8141(91)90016-C.

Hrouda, F., V. Jelinek, and L. Hruskova (1990), A package of programs for statistical evaluation of magnetic data using IBM-PC computers (abstract), Eos Trans. AGU, 1298, San Fransisco, Calif.

Huet, B., L. Labrousse, and L. Jolivet (2009), Thrust or detachment? Exhumation processes in the Aegean: Insight from a field study on los (Cyclades, Greece), Tectonics, 28, TC3007, doi:10.1029/2008TC002397.

Hutton, D. H. W. (1982), A tectonic model for the emplacement of the Main Donegal Granite, NW Ireland, J. Geol. Soc., 139(5), 615-631, doi:10.1144/gsjgs.139.5.0615.

Iglseder, C., B. Grasemann, D. A. Schneider, K. Petrakakis, C. Miller, U. S. Klötzli, M. Thöni, A. Zámolyi, and C. Rambousek (2009), I and S-type plutonism on Serifos (W-Cyclades, Greece), Tectonophysics, 473(1-2), 69-83, doi:10.1016/j.tecto.2008.09.021.

Iglseder, C., B. Grasemann, A. H. N. Rice, K. Petrakakis, and D. A. Schneider (2011), Miocene south directed low-angle normal fault evolution on Kea Island (West Cycladic Detachment System, Greece), Tectonics, 30, TC4013, doi:10.1029/2010TC002802.

Jackson, J. (1994), Active tectonics of the Aegean region, Annu. Rev. Earth Planet. Sci., 22(1), 239-271, doi:10.1146/annurev.earth.22.1.239.

Jelínek, V. (1978), Statistical processing of anisotropy of magnetic susceptibility measured on groups of specimens, Stud. Geophys. Geod., 22(1), 50-62, doi:10.1007/BF01613632.

Jelinek, V. (1981), Characterization of the magnetic fabric of rocks, Tectonophysics, 79(3-4), T63-T67, doi:10.1016/0040-1951(81)90110-4.

Jelínek, V., and J. Pokorný (1997), Some new concepts in technology of transformer bridges for measuring susceptibility anisotropy of rocks, Phys. Chem. Earth, 22(1-2), 179-181, doi:10.1016/S0079-1946(97)00099-2.

Jolivet, L., and J.-P. Brun (2010), Cenozoic geodynamic evolution of the Aegean, Int. J. Earth Sci., 99(1), 109-138, doi:10.1007/s00531-008-0366-4.

Jolivet, L., and C. Faccenna (2000), Mediterranean extension and the Africa-Eurasia collision, Tectonics, 19(6), 1095-1106, doi:10.1029/ 2000TC900018.

Jolivet, L., and M. Patriat (1999), Ductile extension and the formation of the Aegean Sea, Geol. Soc. London Spec. Publ., 156(1), 427-456, doi:10.1144/GSL.SP.1999.156.01.20.

Jolivet, L., J.-P. Brun, P. Gautier, S. Lallemant, and M. Patriat (1994), 3D-kinematics of extension in the Aegean region from the early Miocene to the present; insights from the ductile crust, Bull. Soc. Geol. Fr., 165(3), 195-209.

Jolivet, L., et al. (1998), Midcrustal shear zones in postorogenic extension: Example from the northern Tyrrhenian Sea, J. Geophys. Res., 103(B6), 12123, doi:10.1029/97JB03616.

Jolivet, L., G. Rimmelé, R. Oberhänsli, B. Goffé, and O. Candan (2004), Correlation of syn-orogenic tectonic and metamorphic events in the Cyclades, the Lycian nappes and the Menderes massif. Geodynamic implications, Bull. Soc. Geol. Fr., 175(3), 217-238, doi:10.2113/175.3.217. 
Jolivet, L., E. Lecomte, B. Huet, Y. Denèle, O. Lacombe, L. Labrousse, L. Le Pourhiet, and C. Mehl (2010), The North Cycladic Detachment System, Earth Planet. Sci. Lett., 289(1-2), 87-104, doi:10.1016/j.epsl.2009.10.032.

Jolivet, L., et al. (2013), Aegean tectonics: Strain localisation, slab tearing and trench retreat, Tectonophysics, 597-598, 1-33, doi:10.1016/j.tecto.2012.06.011.

Katzir, Y., A. L. A. N. Matthews, Z. Garfunkel, M. Schliestedt, and D. Avigad (1996), The tectono-metamorphic evolution of a dismembered ophiolite (Tinos, Cyclades, Greece), Geol. Mag., 133(3), 237-254.

Keay, S., and G. Lister (2002), African provenance for the metasediments and metaigneous rocks of the Cyclades, Aegean Sea, Greece, Geology, 30(3), 235, doi:10.1130/0091-7613(2002)030<0235:APFTMA >2.0.CO;2.

Keay, S., G. Lister, and I. Buick (2001), The timing of partial melting, Barrovian metamorphism and granite intrusion in the Naxos metamorphic core complex, Cyclades, Aegean Sea, Greece, Tectonophysics, 342(3-4), 275-312, doi:10.1016/S0040-1951(01)00168-8.

Keefer, C. M., and P. N. Shive (1981), Curie temperature and lattice constant reference contours for synthetic titanomaghemites, J. Geophys. Res., 86(B2), 987-998, doi:10.1029/JB086iB02p00987.

Kokkalas, S., and A. Aydin (2013), Is there a link between faulting and magmatism in the south-central Aegean Sea?, Geol. Mag., 150(02), 193-224, doi:10.1017/S0016756812000453.

Koukouvelas, I. K., and S. Kokkalas (2003), Emplacement of the Miocene west Naxos pluton (Aegean Sea, Greece): A structural study, Geol. Mag., 140(1), 45-61, doi:10.1017/S0016756802007094.

Kratinová, Z., K. Schulmann, J.-B. Edel, J. Ježek, and U. Schaltegger (2007), Model of successive granite sheet emplacement in transtensional setting: Integrated microstructural and anisotropy of magnetic susceptibility study, Tectonics, 26, TC6003, doi:10.1029/2006TC002035.

Kumerics, C., U. Ring, S. Brichau, J. Glodny, and P. Monie (2005), The extensional Messaria shear zone and associated brittle detachment faults, Aegean Sea, Greece, J. Geol. Soc., 162(4), 701-721, doi:10.1144/0016-764904-041.

Lambrakis, N., L. Tiniakos, K. Voudouris, and G. Kallergis (2000), Hydrogeologische Untersuchungen auf der Insel Serifos: Beschaffenheit der granodioritischen Wasser Steir, Beitr. Hydrogeol., 51, 95-110.

Laurent, V., A. Beaudoin, L. Jolivet, L. Arbaret, R. Augier, A. Rabillard, and A. Menant (2015), Interrelations between extensional shear zones and synkinematic intrusions: The example of Ikaria Island (NE Cyclades, Greece), Tectonophysics, doi:10.1016/j.tecto.2015.03.020.

Le Pichon, X., and C. Kreemer (2010), The Miocene-to-present kinematic evolution of the eastern Mediterranean and Middle East and its implications for dynamics, Annu. Rev. Earth Planet. Sci., 38(1), 323-351, doi:10.1146/annurev-earth-040809-152419.

Lecomte, E., L. Jolivet, O. Lacombe, Y. Denèle, L. Labrousse, and L. Le Pourhiet (2010), Geometry and kinematics of Mykonos detachment, Cyclades, Greece: Evidence for slip at shallow dip, Tectonics, 29, TC5012, doi:10.1029/2009TC002564.

Lee, J., and G. S. Lister (1992), Late Miocene ductile extension and detachment faulting, Mykonos, Greece, Geology, 20(2), 121, doi:10.1130/ 0091-7613(1992)020<0121:LMDEAD > 2.3.CO;2.

Lehmann, J., K. Schulmann, J.-B. Edel, J. Ježek, F. Hrouda, O. Lexa, and F. Chopin (2013), Structural and anisotropy of magnetic susceptibility records of granitoid sheets emplacement during growth of a continental gneiss dome (Central Sudetes, European Variscan Belt), Tectonics, 32(3), 797-820, doi:10.1002/tect.20028.

Lister, G. S., and S. L. Baldwin (1993), Plutonism and the origin of metamorphic core complexes, Geology, 21(7), 607, doi:10.1130/0091-7613 (1993)021<0607:PATOOM > 2.3.CO;2.

Lister, G. S., and A. W. Snoke (1984), S-C Mylonites, J. Struct. Geol., 6(6), 617-638, doi:10.1016/0191-8141(84)90001-4.

Lister, G. S., G. Banga, and A. Feenstra (1984), Metamorphic core complexes of Cordilleran type in the Cyclades, Aegean Sea, Greece, Geology, 12(4), 221, doi:10.1130/0091-7613(1984)12<221:MCCOCT>2.0.CO;2.

Maluski, H., M. Bonneau, and J. R. Kienast (1987), Dating the metamorphic events in the Cycladic area; $39 \mathrm{Ar} / 40 \mathrm{Ar}$ data from metamorphic rocks of the Island of Syros (Greece), Bull. Soc. Geol. Fr., 3(5), 833-842.

Marinos, G. (1951), Geology and metallogeny of Serifos island, Geol. Geophys. Res., 1, 95-127.

McCaffrey, K. J. W. (1992), Igneous emplacement in a transpressive shear zone: Ox Mountains igneous complex, J. Geol. Soc., 149(2), 221-235, doi:10.1144/gsjgs.149.2.0221.

McClusky, S., et al. (2000), Global Positioning System constraints on plate kinematics and dynamics in the eastern Mediterranean and Caucasus, J. Geophys. Res., 105(B3), 5695, doi:10.1029/1999JB900351.

Mukherjee, S. (2010), Mineral fish: Their morphological classification, usefulness as shear sense indicators and genesis, Int. J. Earth Sci., 100(6), 1303-1314, doi:10.1007/s00531-010-0535-0.

Nagata, T. (1961), Rock Magnetism, Maruzen Co., Tokyo.

Neves, S. P., A. Vauchez, and C. J. Archanjo (1996), Shear zone-controlled magma emplacement or magma-assisted nucleation of shear zones? Insights from northeast Brazil, Tectonophysics, 262(1-4), 349-364, doi:10.1016/0040-1951(96)00007-8.

Passchier, C. W., and R. A. J. Trouw (2005), Microtectonics, Springer, Berlin.

Paterson, S. R., R. H. Vernon, and O. T. Tobisch (1989), A review of criteria for the identification of magmatic and tectonic foliations in granitoids, J. Struct. Geol., 11(3), 349-363, doi:10.1016/0191-8141(89)90074-6.

Paterson, S. R., G. S. Pignotta, and R. H. Vernon (2004), The significance of microgranitoid enclave shapes and orientations, J. Struct. Geol., 26(8), 1465-1481, doi:10.1016/j.jsg.2003.08.013.

Pérouse, E., N. Chamot-Rooke, A. Rabaute, P. Briole, F. Jouanne, I. Georgiev, and D. Dimitrov (2012), Bridging onshore and offshore present-day kinematics of central and eastern Mediterranean: Implications for crustal dynamics and mantle flow, Geochem. Geophys. Geosyst., 13, Q09013, doi:10.1029/2012GC004289.

Petrakakis, K., C. Iglseder, A. Zámolyi, C. Rambousek, B. Grasemann, E. Draganitis, A. Kurka, and A. Photiades (2007), Geological Map of Serifos. Reilinger, R., S. McClusky, D. Paradissis, S. Ergintav, and P. Vernant (2010), Geodetic constraints on the tectonic evolution of the Aegean region and strain accumulation along the Hellenic subduction zone, Tectonophysics, 488, 22-30, doi:10.1016/j.tecto.2009.05.027.

Ring, U., J. Glodny, T. Will, and S. Thomson (2010), The Hellenic subduction system: High-pressure metamorphism, exhumation, normal faulting, and large-scale extension, Annu. Rev. Earth Planet. Sci., 38(1), 45-76, doi:10.1146/annurev.earth.050708.170910.

Rochette, P., M. Jackson, and C. Aubourg (1992), Rock magnetism and the interpretation of anisotropy of magnetic susceptibility, Rev. Geophys., 30(3), 209, doi:10.1029/92RG00733.

Rochette, P., C. Aubourg, and M. Perrin (1999), Is this magnetic fabric normal? A review and case studies in volcanic formations, Tectonophysics, 307(1-2), 219-234, doi:10.1016/S0040-1951(99)00127-4.

Rohais, S., R. Eschard, M. Ford, F. Guillocheau, and I. Moretti (2007), Stratigraphic architecture of the Plio-Pleistocene infill of the Corinth Rift: Implications for its structural evolution, Tectonophysics, 440, 5-28, doi:10.1016/j.tecto.2006.11.006.

Salemink, J. (1985), Skarn and Ore Formation at Serifos, Greece, as a Consequence of Granodiorite Intrusion, Univ. of Utrecht, Utrecht.

Schliestedt, M., V. Bartsch, M. Carl, A. Matthews, and F. Henjes-Kunst (1994), The P-T path of Greenschist-facies rocks from the island of Kithnos (Cyclades, Greece), Chem. Erde, 54, 281-296. 
Schneider, D. A., C. Senkowski, H. Vogel, B. Grasemann, C. Iglseder, and A. K. Schmitt (2011), Eocene tectonometamorphism on Serifos (western Cyclades) deduced from zircon depth-profiling geochronology and mica thermochronology, Lithos, 125(1-2), 151-172, doi:10.1016/j.lithos.2011.02.005.

Schulmann, K., and J. Ježek (2012), Some remarks on fabric overprints and constrictional AMS fabrics in igneous rocks, Int. J. Earth Sci., 101(3), 705-714, doi:10.1007/s00531-011-0681-z.

Seymour, S., K. D. Zouzias, S. Tombros, and E. Kolaiti (2009), Geochemistry of the Serifos pluton (Cycladic islands) and associated iron oxide and sulfide ores: Skarn or metamorphosed exhalite deposits?, Neues Jahrb. Für Mineral. - Abh., 186(3), 249-270, doi:10.1127/0077-7757/2009/0143.

Simpson, C., and R. P. Wintsch (1989), Evidence for deformation-induced K-feldspar replacement by myrmekite, J. Metamorph. Geol., 7(2), 261-275, doi:10.1111/j.1525-1314.1989.tb00588.x.

Smith, S. A. F., R. E. Holdsworth, and C. Collettini (2011), Interactions between low-angle normal faults and plutonism in the upper crust: Insights from the Island of Elba, Italy, Geol. Soc. Am. Bull., 123(1-2), 329-346, doi:10.1130/B30200.1.

Sparks, R. S. J., and L. A. Marshall (1986), Thermal and mechanical constraints on mixing between mafic and silicic magmas, J. Volcanol. Geotherm. Res., 29(1-4), 99-124, doi:10.1016/0377-0273(86)90041-7.

Stouraiti, C., and P. Mitropoulos (1999), Variation in amphibole composition from the Serifos intrusive complex (Greece), under magmatic and hydrothermal alteration conditions: An application of hornblende geobarometry, Bull. Geol. Soc. Greece, 33, 39-50.

Stouraiti, C., P. Mitropoulos, J. Tarney, B. Barreiro, A. M. McGrath, and E. Baltatzis (2010), Geochemistry and petrogenesis of late Miocene granitoids, Cyclades, southern Aegean: Nature of source components, Lithos, 114(3-4), 337-352, doi:10.1016/j.lithos.2009.09.010.

Ten Grotenhuis, S. M., R. A. J. Trouw, and C. W. Passchier (2003), Evolution of mica fish in mylonitic rocks, Tectonophysics, 372(1-2), 1-21, doi:10.1016/S0040-1951(03)00231-2.

Tikoff, B., and C. Teyssier (1992), Crustal-scale, en echelon "P-shear" tensional bridges: A possible solution to the batholithic room problem, Geology, 20(10), 927, doi:10.1130/0091-7613(1992)020<0927:CSEEPS >2.3.CO;2.

Tobisch, O. T., B. A. McNulty, and R. H. Vernon (1997), Microgranitoid enclave swarms in granitic plutons, central Sierra Nevada, California, Lithos, 40(2-4), 321-339, doi:10.1016/S0024-4937(97)00004-2.

Tommasi, A., A. Vauchez, L. A. D. Femandes, and C. C. Porcher (1994), Magma-assisted strain localization in an orogen-parallel transcurrent shear zone of southern Brazil, Tectonics, 13(2), 421-437, doi:10.1029/93TC03319.

Trotet, F., O. Vidal, and L. Jolivet (2001a), Exhumation of Syros and Sifnos metamorphic rocks (Cyclades, Greece). New constraints on the P-T paths, Eur. J. Mineral., 13(5), 901-920, doi:10.1127/0935-1221/2001/0013/0901.

Trotet, F., L. Jolivet, and O. Vidal (2001b), Tectono-metamorphic evolution of Syros and Sifnos islands (Cyclades, Greece), Tectonophysics, 338(2), 179-206, doi:10.1016/S0040-1951(01)00138-X

Tschegg, C., and B. Grasemann (2009), Deformation and alteration of a granodiorite during low-angle normal faulting (Serifos, Greece), Lithosphere, 1(3), 139-154, doi:10.1130/L33.1.

Turrillot, P., M. Faure, G. Martelet, Y. Chen, and R. Augier (2011), Pluton-dyke relationships in a Variscan granitic complex from AMS and gravity modelling. Inception of the extensional tectonics in the South Armorican Domain (France), J. Struct. Geol., 33(11), 1681-1698, doi:10.1016/j.jsg.2011.08.004.

Van Hinsbergen, D. J. J., E. Hafkenscheid, W. Spakman, J. E. Meulenkamp, and R. Wortel (2005), Nappe stacking resulting from subduction of oceanic and continental lithosphere below Greece, Geology, 33(4), 325, doi:10.1130/G20878.1.

Vanderhaeghe, O. (2004), Structural development of the Naxos migmatite dome, in Gneiss Domes in Orogeny, vol. 380, pp. 211-227, Geol. Soc. of Am., Boulder, Colo.

Vernon, R. H. (1991), Questions about myrmekite in deformed rocks, J. Struct. Geol., 13(9), 979-985, doi:10.1016/0191-8141(91)90050-S.

Vernon, R. H. (2000), Review of microstructural evidence of magmatic and solid-state flow, Visual Geosci., 5(2), 1-23, doi:10.1007/s10069-000-0002-3.

Vernon, R. H., M. A. Etheridge, and V. J. Wall (1988), Shape and microstructure of microgranitoid enclaves: Indicators of magma mingling and flow, Lithos, 22(1), 1-11, doi:10.1016/0024-4937(88)90024-2.

Vigneresse, J. L. (1995), Control of granite emplacement by regional deformation, Tectonophysics, 249(3-4), 173-186, doi:10.1016/0040-195 (95)00004-7.

Villa (1998), Isotopic closure, Terra Nova, 10(1), 42-47, doi:10.1046/j.1365-3121.1998.00156.x.

Wernicke, B. P., P. C. England, L. J. Sonder, and R. L. Christiansen (1987), Tectonomagmatic evolution of Cenozoic extension in the North American Cordillera, Geol. Soc. London Spec. Publ., 28(1), 203-221, doi:10.1144/GSL.SP.1987.028.01.15.

Wijbrans, J. R., and I. McDougall (1988), Metamorphic evolution of the Attic Cycladic Metamorphic Belt on Naxos (Cyclades, Greece) utilizing 40Ar/39Ar age spectrum measurements, J. Metamorph. Geol., 6(5), 571-594, doi:10.1111/j.1525-1314.1988.tb00441.x.

Wijbrans, J. R., M. Schliestedt, and D. York (1990), Single grain argon laser probe dating of phengites from the blueschist to greenschist transition on Sifnos (Cyclades, Greece), Contrib, Mineral. Petrol., 104(5), 582-593, doi:10.1007/BF00306666. 